\title{
Histopathological Investigation of the Stomach of Rats Fed a $60 \%$ Genetically Modified Corn Diet
}

\author{
Irena M. Zdziarski1 ${ }^{*}$, Judy A. Carman ${ }^{2,3 \#, ~ J o h n ~ W . ~ E d w a r d s ~}{ }^{3}$ \\ ${ }^{1}$ Discipline of Anatomy and Pathology, School of Medicine, University of Adelaide, Australia \\ ${ }^{2}$ The Institute of Health and Environmental Research (IHER), Kensington Park, Australia \\ ${ }^{3}$ Health and Environment, College of Science and Engineering, Flinders University, Bedford Park, Australia \\ Email: ^imzdziarski@gmail.com
}

How to cite this paper: Zdziarski, I.M., Carman, J.A. and Edwards, J.W. (2018) Histopathological Investigation of the Stomach of Rats Fed a $60 \%$ Genetically Modified Corn Diet. Food and Nutrition Sciences, 9, 763-796.

https://doi.org/10.4236/fns.2018.96058

Received: April 28, 2018

Accepted: June 26, 2018

Published: June 29, 2018

Copyright $\odot 2018$ by authors and Scientific Research Publishing Inc. This work is licensed under the Creative Commons Attribution International License (CC BY 4.0).

http://creativecommons.org/licenses/by/4.0/

\begin{abstract}
Genetic modification (GM) represents new opportunities for enhanced crop features such as improved insect resistance and herbicide tolerance. The technology allows for cross-species alterations, therefore potentially allowing a vast array of novel traits. Many GM crops have been developed and approved for human and animal consumption. The present study investigated a triple-stacked GM corn variety containing modifications for insect resistance (via $c r y 1 A b$ and $c r y 3 B b 1$ genes) and herbicide tolerance (via an EPSPS gene), which was fed to rats for six months. The study investigated the mucosa of the stomach. Alterations to tight junction apposition, gland dilatations with epithelial elongation and dysplasia in the GM-fed rats were observed. These results indicate that GM-corn may have an effect on rat stomach mucosa, which may have health implications.
\end{abstract}

\section{Keywords}

Genetically Modified Corn, Rat Feeding Study, Long-Term Feeding Study, Histopathology, Stomach

\section{Introduction}

Genetically modified (GM; transgenic) crops have been grown for human and animal consumption since the 1990's [1]. Most currently-grown crops have been developed through the transfer and incorporation of a gene cassette into the

\#Judy A. Carman is currently affiliated with IHER (Affiliation 2) and was previously affiliated with Flinders University (Affiliation 3). 
plants. This cassette contains inter alia plant, bacterial and/or viral genes [2] [3]. In this way, traits have been generated that would not otherwise be achievable via conventional plant breeding, including cross-species alterations. The gene cassette contains the desired traits as well as other DNA needed for successful transformation and identification of the transformed crop. The two most common traits thus produced are insect resistance and herbicide tolerance [2]. "Stacked" crops, which contain more than one trait, are becoming more prevalent [4]. In the United States of America in 2016, 76\% of the cultivated corn consisted of stacked GM varieties [5].

Food regulators, such as Food Standards Australia New Zealand (FSANZ), have assessed numerous GM crops and concluded that they were substantially equivalent to non-GM varieties, unless they were designed to be substantially different, such as a GM plant that was designed to have a different fatty acid profile [6] [7]. Animal feeding studies are often not performed or required [6] [7]. In addition, in many countries, crops containing several stacked genes are not required to be safety assessed if all the genes in the stack have previously been individually approved for use in the same kind of plant [8] [9]. In the European Union recently, new legislative requirements have been put in place that require additional safety assessments, which include mandatory rat feeding trials [10]. However, this is not retrospective and only applies to newly developed crops.

In contrast, numerous detailed and systematic investigations are required prior to the approval of a new pharmaceutical drug. In particular, investigations evaluate the safety of each component of the drug and the combined effect of these components.

Thus far, few comprehensive investigations of the effect of GM crops on animal or human health have been published [11] [12] [13]. Furthermore, many of these studies measured animal production outcomes in farmed animals that are not physiologically comparable to humans and the measured variables were limited to those such as body weight, meat yield or milk production [14] [15] [16] [17]. These do not adequately reflect human or animal health outcomes [14].

Longer-term toxicological studies investigating histopathological effects of GM crop consumption in animals that are physiologically similar to humans are scarce [11] [12] [14]. We recently published a review of histopathological studies investigating the digestive tract of rats fed a GM diet for 90 days or longer [13]. The purpose of the literature review was to examine the relationship between GM crops and histopathological observations in rats, since the rat model is the accepted OECD standard for toxicological studies of this type [18]. A consideration of the digestive tract was deemed important since it is the first site of contact for any ingested compound, and hence the first site of possible toxicological or pathological changes that may arise due to a GM diet. The search was limited to long-term rat feeding studies of no less than 90 days duration and crops possessing one or more of three specific traits which are commonly found in commercialised GM crops: herbicide tolerance via an EPSPS gene, and insect resis- 
tance via $c r y 1 A b$ or $c r y 3 B b 1$ genes [13]. Our study revealed that only $19 \%$ of the GM crops, known to possess at least one of the traits of interest, had been investigated via long-term feeding trials. No published rat-feeding studies could be found for the remaining $81 \%$ of approved crops. Of all the published studies found, only $57 \%$ performed an overall general health assessment of the long-term effect of GM feed on rat health. However, these studies lacked defined criteria for outcomes that would be considered toxicologically or pathologically significant, and more importantly, they lacked transparency in their methods and their results obtained. These omissions make it difficult to compare studies, to perform further research, and to determine the safety of GM crops.

Furthermore, the previously published papers rarely utilised anything other than the regular haematoxylin and eosin (H\&E) staining. Haematoxylin and eosin is a general stain that stains nucleic acids a deep blue-purple colour and non-specifically stains proteins a pink colour. Therefore, it is commonly used for identifying tissue structure and hence can help identify whether the tissue has become morphologically abnormal [19]. There are, however, other stains that can identify specific structures or cell properties, such as collagen (Masson's trichrome or picrosirius red) and mucins and glycogen (alcian blue and periodic acid Schiff; AB/PAS). These can help quantitate the structural, physiological and possible pathological properties of the tissue, such as an increase in collagen fibres (which often follows mucosal injury) or the presence of intestinal-like cells in the stomach (indicative of intestinal metaplasia). There are also more specific histological methods, such as immunohistochemistry that use antibodies for specific markers of change, for example apoptosis (caspase 3 antibody) or cell division/proliferation (Ki67 antibody). Electron microscopy is yet another specific histological method that provides even more detailed morphological data at an ultrastructural level. In other fields of study, at least one of these methods is utilised to assess mammalian health [20] [21] [22] [23].

In 2013, our group published a long-term toxicology feeding study on pigs fed a mixed diet of GM soy and GM corn containing three common traits via the EPSPS gene, and $c r y 1 A b$ or $c r y 3 B b 1$ genes [24]. The authors reported that the GM diet caused an increase in severe stomach inflammation, measured as surface redness and swelling that was 2.2 times higher in female pigs and 4.0 times higher in male pigs on the GM diet compared with pigs on the control diet. The authors suggested that the inflammation may be due to the presence of the two insecticidal proteins, Cry3Bb1 and Cryl Ab in the diet. In the insect gut, these proteins are suggested to act on the gut according to two models. In the signal transduction model, the toxin binds to cadherin (a cell membrane protein) [25], which induces a cascade of events resulting in cell death [26] [27]. In the pore-forming model, the toxin binds to cadherin, which initiates oligomeristation and subsequent pore-formation in the apical membrane of the gut epithelium [25] [28]. While it has been suggested that these proteins cannot harm the gut of mammals because mammals lack the necessary gut environment and spe- 
cific receptors [29], several studies indicate that this may not be the case. One in vitro study found Cry proteins binding to the apical surface of mouse small intestine epithelial cells, as well as hyperpolarisation of the intestine, which is consistent with the pore-forming action of the Cry proteins [30]. Another study found ultrastructural changes to enterocytes and hyperplasia in the ileum of mice fed for two weeks on a diet containing a Cry protein-producing GM potato or a non-GM potato diet which had the Cry protein added [31].

The present study aimed to investigate the effects of a triple-stacked GM corn variety on the rat digestive tract. The GM corn contained modifications for herbicide tolerance via the EPSPS gene, and insect resistance via $c r y 1 A b$ or $c r y 3 B b$, the same genes investigated in our earlier pig toxicology study. Rats were chosen, since they are the standard model for this kind of research [18] and their organs are of a particularly suitable size for microscopic morphometric analyses. Male rats were investigated, since this gender exhibited higher levels of stomach inflammation in pigs. We further ensured that our assessment contained widely-accepted criteria and reproducible materials and methods, which included a range of microscopic and morphometric methods, in order to look for signs indicating a pathological change. In particular, the presence of proliferation and apoptosis in the mucosal tissue were investigated using antibodies for Ki67 and active caspase 3 respectively. We did not, however, investigate neoplastic or vascular changes.

The FAO/WHO recommend that long-term feeding studies be a minimum 90 days duration [6]. We doubled the minimum time, so as to better assess the effect of the long-term consumption of a GM crop on the gastrointestinal tract of the rat. The FAO/WHO further recommend that animal feeding studies investigating GM crop consumption should investigate the effects at a range of dose levels. The highest dose is the maximum achievable dose that would not cause nutritional imbalance in the test animal, and the lowest dose is the dose that closely resembles the anticipated human intake [6]. We used the maximum achievable dose of corn for semi-purified diets, which is $60 \%$ according to the feed manufacturer.

\section{Materials and Methods}

All procedures were performed under ethics approval (project no. 646/07) from the Animal Welfare Committee of Flinders University, South Australia. All animal work was performed in accordance with the South Australian Prevention of Cruelty to Animals Act (1985) and with the Australian Code of Practice for the Care and Use of Animals for Scientific Purposes (2004). All animal husbandry, necropsy, and histopathological assessments were performed under blinded conditions.

\subsection{Diet}

The triple-stacked GM corn variety, containing the MON863, MON810 and 
NK603 genes, was obtained from a farmer who had grown it in the United States (US).

It was not possible to obtain an isogenic or near-isogenic variety to use in a control corn diet. An isogenic variety is the specific parental (non-GM) corn variety that is transformed to make the GM variety. As the GM corn used was made by conventionally crossing several GM varieties, there is no isogenic or parental non-GM variety available. Consequently, the control diet contained a commercially-grown non-GM corn grown in Australia. The corn was not sourced from the US due to the difficulties in finding a non-GM corn variety from that country that would be completely uncontaminated, as our previous study has shown [24]. In contrast, Australia does not grow any GM corn, either commercially or in field trials [2] [4] [32], which should guarantee that the non-GM diet contained no GM material.

The GM parental lines as well as the triple-stacked GM corn used in this study have been determined to be compositionally equivalent to non-GM corn varieties by various government regulators [16] [33] [34] [35] [36] [37]. Therefore, according to these government regulators, there should be no phenotypical variation between the GM and non-GM varieties used that could influence the outcomes measured in this study [35].

The two diets, containing either GM or non-GM corn at $60 \%$ of the diet, were semi-purified diets, formulated by Specialty Feeds (Glen Forrest, Australia) to meet the nutritional requirements for the growth and well-being of rats (i.e. comparable with the standard rat diet, AIN-93G Growth Purified Diet) (Table 1). Other than the GM/non-GM nature of the corn, all other aspects of the diet were the same between the two diets.

\subsection{Animal Feeding and Necropsy}

Twenty unweaned, male, outbred Sprague Dawley rats weighing $50 \mathrm{~g} \pm 15 \mathrm{~g}$ were obtained at 3 weeks of age and were weaned onto the non-GM control diet. After a week, they were randomly placed into one of two groups, GM-fed ( $\mathrm{n}=$ 10) and non-GM-fed $(n=10)$. Rats had ad libitum access to water and feed. Animal rooms were maintained at $21^{\circ} \mathrm{C} \pm 2{ }^{\circ} \mathrm{C}$ temperature, $40 \%$ - $60 \%$ humidity and a $12 \mathrm{~h}$ light/dark cycle. Rats were monitored daily and weighed weekly. After 26 weeks, rats were weighed, anaesthetised with isoflurane and euthanized via the removal of the heart. The stomach was removed immediately post-mortem by a certified veterinarian, an incision was made along the greater curvature, the stomach contents were removed, and the inner surface was flushed with phosphate buffered saline (PBS). The stomachs were then weighed. One half was fixed in 10\% buffered formalin ( $\mathrm{pH}$ 7.4) for $12-18 \mathrm{~h}$ (overnight) and routinely processed for light microscopy. From the other half, $1 \mathrm{~mm}$ by $1 \mathrm{~mm}$ sections of the fundus wall were fixed in a solution containing $2 \%$ glutaraldehyde, $3 \%$ paraformaldehyde in $0.1 \mathrm{M}$ phosphate buffer ( $\mathrm{pH} 7.4$ ), and processed for electron microscopy. 
Table 1. Diet specifications as determined by specialty feeds (glen forrest, Australia), comparable with the standard rat diet, AIN-93G growth purified diet.

\begin{tabular}{|c|c|}
\hline \multicolumn{2}{|c|}{ Calculated Nutritional Parameters } \\
\hline Protein & $18 \%$ \\
\hline Total fat & $6.0 \%$ \\
\hline Crude fibre & $6.1 \%$ \\
\hline Acid detergent fibre & 6.1 \\
\hline Digestible energy & $15.0 \mathrm{MJ} / \mathrm{kg}$ \\
\hline \multicolumn{2}{|c|}{ Ingredients } \\
\hline Casein (acid) & $132 \mathrm{~g} / \mathrm{kg}$ \\
\hline Ground maize & $600 \mathrm{~g} / \mathrm{kg}$ \\
\hline Canola oil & $40 \mathrm{~g} / \mathrm{kg}$ \\
\hline DL methionine & $3.0 \mathrm{~g} / \mathrm{kg}$ \\
\hline Wheat starch & $140 \mathrm{~g} / \mathrm{kg}$ \\
\hline Cellulose & $50 \mathrm{~g} / \mathrm{kg}$ \\
\hline Calcium carbonate & $13 \mathrm{~g} / \mathrm{kg}$ \\
\hline Sodium chloride & $2.6 \mathrm{~g} / \mathrm{kg}$ \\
\hline Potassium citrate & $2.5 \mathrm{~g} / \mathrm{kg}$ \\
\hline Potassium dihydrogen phosphate & $2.8 \mathrm{~g} / \mathrm{kg}$ \\
\hline Potassium sulphate & $0.4 \mathrm{~g} / \mathrm{kg}$ \\
\hline AIN93G trace minerals & $1.4 \mathrm{~g} / \mathrm{kg}$ \\
\hline Choline chloride (65\%) & $2.5 \mathrm{~g} / \mathrm{kg}$ \\
\hline AIN93G vitamins & $10 \mathrm{~g} / \mathrm{kg}$ \\
\hline \multicolumn{2}{|c|}{ Calculated Amino Acids } \\
\hline Valine & $1.1 \%$ \\
\hline Leucine & $1.8 \%$ \\
\hline Isoleucine & $0.7 \%$ \\
\hline Threonine & $0.7 \%$ \\
\hline Methonine & $0.7 \%$ \\
\hline Cystine & $0.2 \%$ \\
\hline Lysine & $1.1 \%$ \\
\hline Phenylalanine & $0.9 \%$ \\
\hline Tyrosine & $0.9 \%$ \\
\hline Tryptophan & $0.2 \%$ \\
\hline \multicolumn{2}{|c|}{ Calculated Total Minerals } \\
\hline Calcium & $0.46 \%$ \\
\hline Phosphorous & $0.33 \%$ \\
\hline Magnesium & $0.20 \%$ \\
\hline Sodium & $0.11 \%$ \\
\hline Chloride & $0.17 \%$ \\
\hline Potassium & $0.35 \%$ \\
\hline Sulphur & $0.2 \%$ \\
\hline
\end{tabular}




\section{Continued}

\begin{tabular}{|c|c|}
\hline Iron & $100 \mathrm{mg} / \mathrm{kg}$ \\
\hline Copper & $10 \mathrm{mg} / \mathrm{kg}$ \\
\hline Iodine & $0.22 \mathrm{mg} / \mathrm{kg}$ \\
\hline Manganese & $20 \mathrm{mg} / \mathrm{kg}$ \\
\hline Zinc & $43 \mathrm{mg} / \mathrm{kg}$ \\
\hline Selenium & $0.25 \mathrm{mg} / \mathrm{kg}$ \\
\hline Chromium & $2.0 \mathrm{mg} / \mathrm{kg}$ \\
\hline Lithium & $0.1 \mathrm{mg} / \mathrm{kg}$ \\
\hline Boron & $0.7 \mathrm{mg} / \mathrm{kg}$ \\
\hline Nickel & $0.55 \mathrm{mg} / \mathrm{kg}$ \\
\hline Vanadium & $0.10 \mathrm{mg} / \mathrm{kg}$ \\
\hline \multicolumn{2}{|c|}{ Calculated Total Vitamins } \\
\hline Vitamin A (Retinol) & $8000 \mathrm{IU} / \mathrm{kg}$ \\
\hline Vitamin D3 (Cholecalciferol) & $1000 \mathrm{IU} / \mathrm{kg}$ \\
\hline Vitamin E (Tocopherol acetate) & $90 \mathrm{mg} / \mathrm{kg}$ \\
\hline Vitamin K (Menadione) & $1 \mathrm{mg} / \mathrm{kg}$ \\
\hline Vitamin B1 (Thiamine) & $8 \mathrm{mg} / \mathrm{kg}$ \\
\hline Vitamin B2 (Riboflavin) & $7 \mathrm{mg} / \mathrm{kg}$ \\
\hline Niacin (Nicotinic acid) & $43 \mathrm{mg} / \mathrm{kg}$ \\
\hline Vitamin B6 (Pyridoxine) & $11 \mathrm{mg} / \mathrm{kg}$ \\
\hline Pantothenic acid & $20 \mathrm{mg} / \mathrm{kg}$ \\
\hline Biotin & $240 \mu \mathrm{g} / \mathrm{kg}$ \\
\hline Folic acid & $2 \mathrm{mg} / \mathrm{kg}$ \\
\hline Vitamin B12 (Cyanocobalamin) & $100 \mathrm{mg} / \mathrm{kg}$ \\
\hline Choline & $2000 \mathrm{mg} / \mathrm{kg}$ \\
\hline \multicolumn{2}{|c|}{ Calculated Fat Composition } \\
\hline Myristic acid 14:0 & trace \\
\hline Palmitic acid $16: 0$ & $0.4 \%$ \\
\hline Stearic acid 18:0 & $0.1 \%$ \\
\hline Palmitoleic acid 16:1 & trace \\
\hline Oleic acid 18:1 & $2.7 \%$ \\
\hline Gadoleic acid 20:1 & trace \\
\hline Linoleic acid 18:2 n6 & $2.0 \%$ \\
\hline a Linoleic acid 18:3 n3 & $0.6 \%$ \\
\hline
\end{tabular}

\subsection{Light Microscopy}

Fixed samples were processed, and embedded in paraffin wax. Sections (5 - $6 \mu \mathrm{m}$ thick) were cut using a rotary microtome and mounted on glass slides with two sections per slide. A second section of the stomach was taken at a minimum depth of $300 \mu \mathrm{m}$ from the first and mounted on a separate slide in order to obtain a greater field of study. Slides were routinely stained with $\mathrm{H} \& \mathrm{E}$ and with combined $\mathrm{AB} / \mathrm{PAS}(\mathrm{pH} 2.5)$. Sections were viewed under a light microscope and 
morphometric analyses were performed using NIS-Elements BR (Nikon) software. A general assessment of the gastric mucosa was performed using the Updated Sydney System (USS) [38]. When this System is applied to rats, it assesses the degree of inflammation, gland or pit atrophy or hyperplasia, and the presence/degree of intestinal metaplasia. All observations and analyses were performed under blinded conditions.

In the non-glandular stomach, the thickness of the keratinized and non-keratinized epithelial layers was measured in areas of thinnest mucosal thickness. In the glandular stomach (fundic region), the pit and gland depth and mucosa thickness were obtained in at least 20 well-orientated areas. Granular leukocytes (GL) were counted in the lamina propria below the gastric glands. This was performed in areas where the muscularis mucosae and the base of the mucosal glands were well defined. The procedure was as follows: Using NIS-Elements BR (Nikon) software and a light microscope with a 20x objective lens, an area of interest was outlined and the area recorded. Granular leukocytes, found in the marked area, were counted and a percentage of GL per area was obtained. Granular leukocytes were defined as those containing a bright pink cytoplasm and a multi-lobed nucleus. This procedure was repeated randomly along the length of the stomach. The total area measured per rat was an average of $0.16 \mathrm{~mm}^{2}$.

\subsection{Immunohistochemistry}

Caspase 3 and Ki67

Caspase 3 is a cysteine protease primarily present in the cytoplasm and nucleus of cells in the terminal effector phases of apoptosis [39]. Apoptosis is physiological cell death, commonly termed as "programmed cell death", that naturally occurs during tissue remodelling, to maintain tissue homeostasis, to remove senescent cells, and to delete cells with genetic damage [40] [41]. In the present study, the antibody used to label caspase 3 was of the active form. In the stomach section, using the peroxidase method, apoptotic cells appear brown, while non-apoptotic cells appear clear with a blue nucleus.

$\mathrm{Ki} 67$ is a nuclear protein that is present throughout the active cell cycle of proliferating cells (late $G_{1}, S, G_{2}$, and $M$ phases), but is absent in quiescent $\left(G_{0}\right)$ cells [42] [43]. Therefore, in the stomach section, using the peroxidase method, nuclei of proliferative cells appears brown, while nuclei of non-proliferative cells appear blue.

Sections were cut at $4 \mu \mathrm{m}$, mounted on DAKO slides and dried overnight at $30^{\circ} \mathrm{C}$. Slides were deparaffinised in histolene and rehydrated in graded ethanol solutions to distilled water. Antigen retrieval was performed using high $\mathrm{pH}$ antigen retrieval solution (DAKO) and set on a 20 min cycle at $100^{\circ} \mathrm{C}$ (DAKO PT Link). Using an automated cycle (DAKO Autostainer Plus), sections were first quenched with $3 \%$ hydrogen peroxide (FLEX peroxidase blocker, DAKO) for 5 min and then immersed in Protein Block (DAKO) for $30 \mathrm{~min}$, followed by a 60 min incubation in primary antibody, active caspase 3 (1:1000 dilution, abcam ab4051) or Ki67 (1:1000 dilution, abcam ab16667). Sections were then labelled 
with anti-rabbit horseradish peroxidase (HRP) (30 min, DAKO) and developed with 3,3-diaminobenzidine (DAB; DAKO) for $10 \mathrm{~min}$, washed with distilled water, manually counterstained with Harris haematoxylin $(10 \mathrm{sec})$, blued in ammonia solution ( $1 \mathrm{~min}$ ), dehydrated in a graded series of ethanol and histolene, and cover slipped with DPEX mounting medium.

In the stomach (fundus), cell counts were performed in well-orientated areas, $3 \mathrm{~mm}$ from the glandular/non-glandular stomach junction, and $100 \mu \mathrm{m}$ from the fundus/pylorus junction [44]. Using NIS-Elements BR (Nikon) software, a 100 $300 \mu \mathrm{m}$-wide area was outlined perpendicular to the mucosa and comprising the entire thickness of the mucosa. Within this area, all labelled and unlabelled epithelial cells/nuclei were counted [44] [45]. This procedure was repeated one to four times per rat. The results were expressed as the ratio of caspase 3- or Ki67-labelled cells/nuclei to the total number of cells/nuclei counted [45] [46].

\subsection{Electron Microscopy}

Fixed sections of glandular stomach were secondarily fixed in $1 \%$ osmium tetroxide, routinely processed for transmission electron microscopy (TEM) and embedded in epoxy resin. Thin sections $(70-90 \mathrm{~nm})$ were cut with an ultra-microtome, mounted on $\mathrm{Cu} / \mathrm{Pd}$ grids and assessed for morphological changes using a Phillips CM100 Transmission Electron Microscope.

Tight junction integrity between epithelial cells lining the surface of gastric pits was assessed using the grading system reported by reference [47]. Tight junctions were examined at a final magnification of 43,000. A tight junction was assessed as either: open, closed, or cut obliquely. The latter were not counted because the poor orientation of the section would have resulted in inaccurate counts. A tight junction was considered closed if there was no gap between opposing cells at the luminal end and no gap between opposing leaflets of the tight junction [47]. Tight junctions were assessed between well-orientated cells cut in cross-section, which means the cells' luminal surface had to be clearly defined and their basal surface had to be sitting on a basement membrane. This prevented false positive identification of tight junction poor apposition. A minimum of 20 junctions were assessed per rat.

\subsection{Severity Score}

Observations or results that could be deemed adverse, irrespective of whether they appeared in the GM-fed or non-GM-fed rat, such as poor tight junction apposition or alterations to the staining properties of the epithelium, were tabulated and added to give each rat a severity score.

\subsection{Statistical Analysis}

All statistical analyses were performed in accordance with the OECD Environment Directive on working with chemicals, pesticides and biotechnology [48].

Statistical analyses of continuous data were conducted using SPSS version 20 and 22. The results were averaged for each rat and then the results for all rats in 
the same dietary group were tested for normal distribution using the Shapiro-Wilk test. If data for both groups were normally distributed, a t-test was performed. Additionally, Levene's test for equality of variances was performed and the appropriate $\mathrm{p}$ value for the $\mathrm{t}$-test was reported. If data for both groups were not normally distributed, a Mann Whitney U test was used. A 2-tailed test was used, unless otherwise stated and $p<0.050$ was considered significant. In the data set, while SPSS occasionally found outliers, none were extreme, thus no outliers were removed.

Statistical analyses of categorical data were conducted using Epi Info ${ }^{\mathrm{ra}}$ version 7 (developed by the US Centres for Disease Control and Prevention). Results were reported as a relative risk (also known as a risk ratio; RR) and associated 95\% confidence interval. Fisher's Exact $\mathrm{p}$ value was reported since sample sizes were generally low and the expected numbers in the tables' cells were often less than five. A $p<0.050$ was considered significant.

\section{Results}

\subsection{Animal Feeding}

After randomisation, there was no difference between the body weights of the GM-fed and non-GM-fed groups. Over the next few weeks, it was noticed that the dietary intake of both groups of rats was not as high as expected and that the GM-fed rats were eating less than the non-GM-fed rats. Neither group of rats lost weight. The diet manufacturer suggested that the moisture content of the diets should be increased. The diets were therefore sent for repelleting, starting with the GM diet, because they were the group with the lowest dietary intake. The provision of moister diets resulted in a typical weight gain [49] for the remainder of the study. Because the GM-fed rats were fed those diets a few weeks before non-GM-fed rats, they weighed more at the end of the study compared to non-GM-fed rats. Consequently, no conclusions can be drawn about the effect of the GM diet on body weight. Furthermore, because larger animals could be expected to have larger stomachs, the stomach weight was expressed as a proportion of body weight. The mean stomach weight to body weight ratio (and interquartile range) were $0.46(0.44-0.50)$ and $0.43(0.40-0.49)$ for non-GM and GM-fed rats respectively. The difference was not statistically significant.

Of importance, the total dietary intake over the course of the experiment indicates that the study has become more conservative in its findings, that is, any effects of the GM diet on the stomachs of rats has been underestimated. This is clarified in the discussion.

\subsection{Light Microscopy}

\subsubsection{Non-Glandular Stomach}

One non-GM-fed animal had a grossly enlarged squamous cell cyst. No other abnormal changes were observed in either the GM-fed or non-GM-fed groups. Mucosal thickness measurements revealed no differences between the groups (Table 2). 
Table 2. Morphometric analyses and cell counts from the stomach mucosa of rats fed a $60 \%$ GM or non-GM corn diet.

\begin{tabular}{|c|c|c|c|c|c|c|c|c|}
\hline & \multicolumn{3}{|c|}{ GM } & \multicolumn{3}{|c|}{ Non-GM } & \multirow{2}{*}{$\begin{array}{l}\text { Statistical } \\
\text { Significance } \\
(\mathrm{p}<0.050)\end{array}$} & \multirow{2}{*}{$\begin{array}{l}\text { Percentage } \\
\text { Change }(\%)^{\mathrm{b}}\end{array}$} \\
\hline & $\begin{array}{l}\text { Mean or } \\
\text { median }^{\text {a }}\end{array}$ & $\mathrm{SD}$ or $\mathrm{IQR}^{\mathrm{a}}$ & $\mathrm{n}$ & $\begin{array}{l}\text { Mean or } \\
\text { median }^{\text {a }}\end{array}$ & $\mathrm{SD}$ or $\mathrm{IQR}^{\mathrm{a}}$ & $\mathrm{n}$ & & \\
\hline \multicolumn{9}{|c|}{ Non-Glandular Stomach } \\
\hline Average mucosal thickness $(\mu \mathrm{m})$ & 57.41 & 6.15 & 5 & 59.80 & 8.90 & 5 & NS & -4.00 \\
\hline $\begin{array}{l}\text { Average thickness of } \\
\text { keratinized layer }(\mu \mathrm{m})\end{array}$ & 8.13 & $7.40-8.23$ & 5 & 8.53 & $7.65-8.75$ & 5 & NS & -4.69 \\
\hline $\begin{array}{c}\% \text { keratinized layer/mucosal } \\
\text { thickness }\end{array}$ & 13.83 & $13.47-14.85$ & 5 & 13.79 & $12.23-15.12$ & 5 & NS & 0.29 \\
\hline $\begin{array}{c}\text { Average thickness of } \\
\text { non-keratinized layer }(\mu \mathrm{m})\end{array}$ & 48.41 & 3.62 & 5 & 51.57 & 7.90 & 5 & NS & -6.13 \\
\hline $\begin{array}{c}\% \text { non-keratinized } \\
\text { layer/mucosal thickness }\end{array}$ & 86.17 & $85.15-86.53$ & 5 & 86.71 & $84.88-87.77$ & 5 & NS & -0.62 \\
\hline \multicolumn{9}{|c|}{ Glandular Stomach - Fundus } \\
\hline Average mucosal thickness $(\mu \mathrm{m})$ & 762.01 & 80.41 & 10 & 737.37 & 100.28 & 10 & NS & 3.34 \\
\hline Average pit depth $(\mu \mathrm{m})$ & 99.03 & 12.51 & 10 & 93.47 & 12.20 & 10 & NS & 5.95 \\
\hline$\%$ pit depth/mucosal thickness & 13.13 & 2.14 & 10 & 12.94 & 2.82 & 10 & NS & 1.47 \\
\hline Average gland depth $(\mu \mathrm{m})$ & 622.18 & 76.95 & 10 & 609.32 & 95.30 & 10 & NS & 2.11 \\
\hline$\%$ gland depth/mucosal thickness & 81.55 & 2.99 & 10 & 82.42 & 2.68 & 10 & NS & -1.06 \\
\hline Average pit + gland depth $(\mu \mathrm{m})$ & 721.20 & 75.54 & 10 & 702.79 & 93.22 & 10 & NS & 2.62 \\
\hline $\begin{array}{c}\% \text { pit }+ \text { gland depth } / \text { mucosal } \\
\text { thickness }\end{array}$ & 95.50 & $94.58-95.90$ & 10 & 95.38 & $94.75-96.45$ & 10 & NS & 0.13 \\
\hline $\begin{array}{l}\text { Average thickness of lamina } \\
\text { propria below glands }(\mu \mathrm{m})\end{array}$ & 40.81 & 16.70 & 10 & 34.58 & 11.40 & 10 & NS & 18.02 \\
\hline $\begin{array}{l}\text { \% lamina propria thickness below } \\
\text { gland/mucosal thickness }\end{array}$ & 4.50 & $4.10-5.42$ & 10 & 4.62 & $3.55-5.25$ & 10 & NS & -2.60 \\
\hline $\begin{array}{l}\% \text { granular leukocyte } \\
\text { count/lamina } \\
\text { propria area below gland }\end{array}$ & 0.11 & 0.05 & 10 & 0.16 & 0.10 & 10 & NS & -31.25 \\
\hline Gland dilatation severity score & 2.50 & $0.00-3.00$ & 10 & 0.00 & $0.00-1.00$ & 10 & NS & Undefined \\
\hline
\end{tabular}

${ }^{\mathrm{a}}$ For non-normally distributed data, the median and interquartile range (IQR) are given. $\mathrm{SD}=$ standard deviation. ${ }^{\mathrm{b}}$ The effect of the GM diet compared with the non-GM diet as a Percentage Change. The means were compared, unless one or both variables were not normally distributed, when the medians were compared. A negative sign before the number indicates that the GM diet decreased the variable. No sign indicates that the GM diet increased the value of the variable.

\subsubsection{Glandular Stomach}

Morphometric analyses showed increases in mucosal thickness, and pit and gland depth in the GM-fed compared with the non-GM-fed group. However, these results were not statistically significant (Table 2; Figure 1). Mononuclear inflammatory cells were rarely seen in the pit and glandular region of the mucosa. In most animals of both groups, granular leukocyte infiltration was mild as defined by the USS [38] and was primarily located in the lamina propria of the deep glandular region (Figure 2). In two non-GM-fed animals, the infiltration was moderate according to USS. Furthermore, a count of granularleukocytes in 


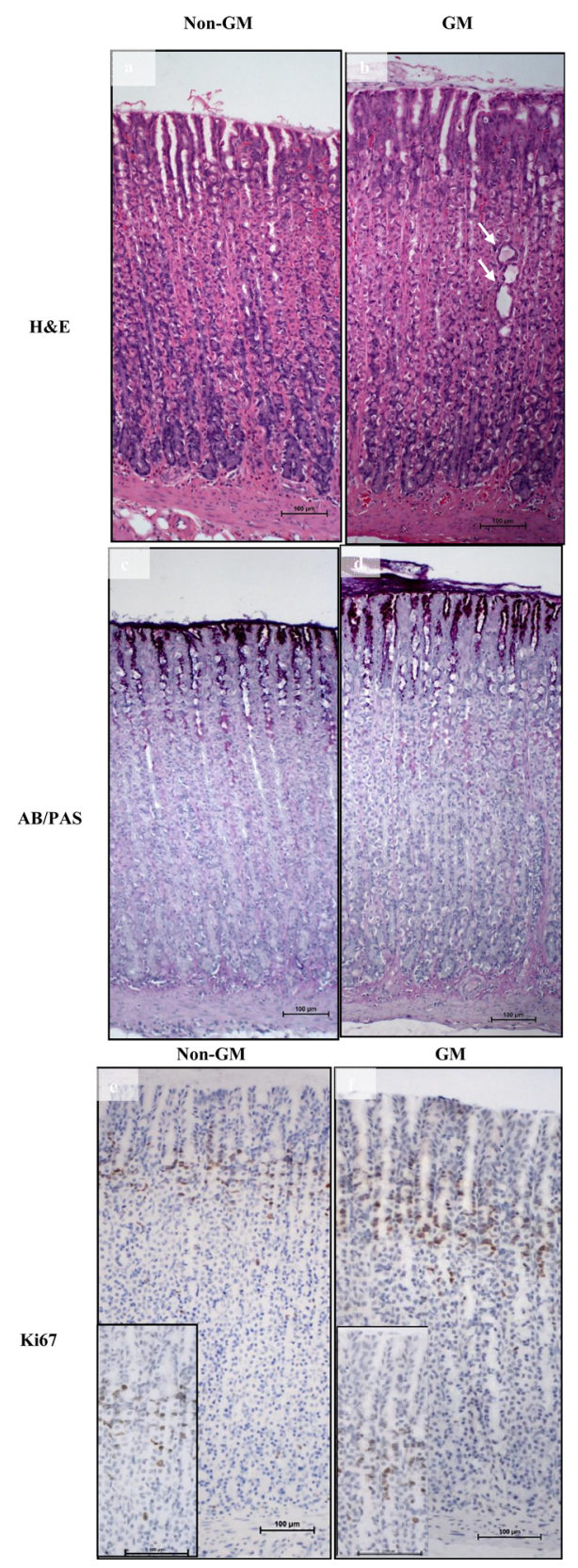

Figure 1. Sections of the stomach (fundus) of rats fed a $60 \%$ GM or non-GM corn diet. H\&E stained sections of the stomach mucosa of: (a) a non-GM-fed rat, and (b) a GM-fed rat. The section from the GM-fed animal clearly shows a thicker mucosa (not statistically significant), as well as a gland dilatation lined with elongated epithelial cells (arrows) ( $p=$ 0.011). There does not appear to be any increase in connective tissue fibres in either of the sections. AB/PAS stained sections of the stomach mucosa of: (c) a non-GM rat, and (d) a GM-fed rat. The mucus-producing cells in the gastric pits stain dark purple indicative of their neutral mucins. The glands of both sections appear to be uniformly stained. The section from the GM-fed rat shows deeper pits and glands than the non-GM-fed rat (not statistically significant). Nuclei of proliferating cells labelled with Ki67 antibody as seen in the sections of the stomach mucosa of: (e) a non-GM rat, and (f) a GM-fed rat. Insets show the pit and neck regions at higher magnification. Labelling is primarily seen in the nuclei of epithelial cells of the neck region (between the gastric pits and glands). Scale bars $=100 \mu \mathrm{m}$. 


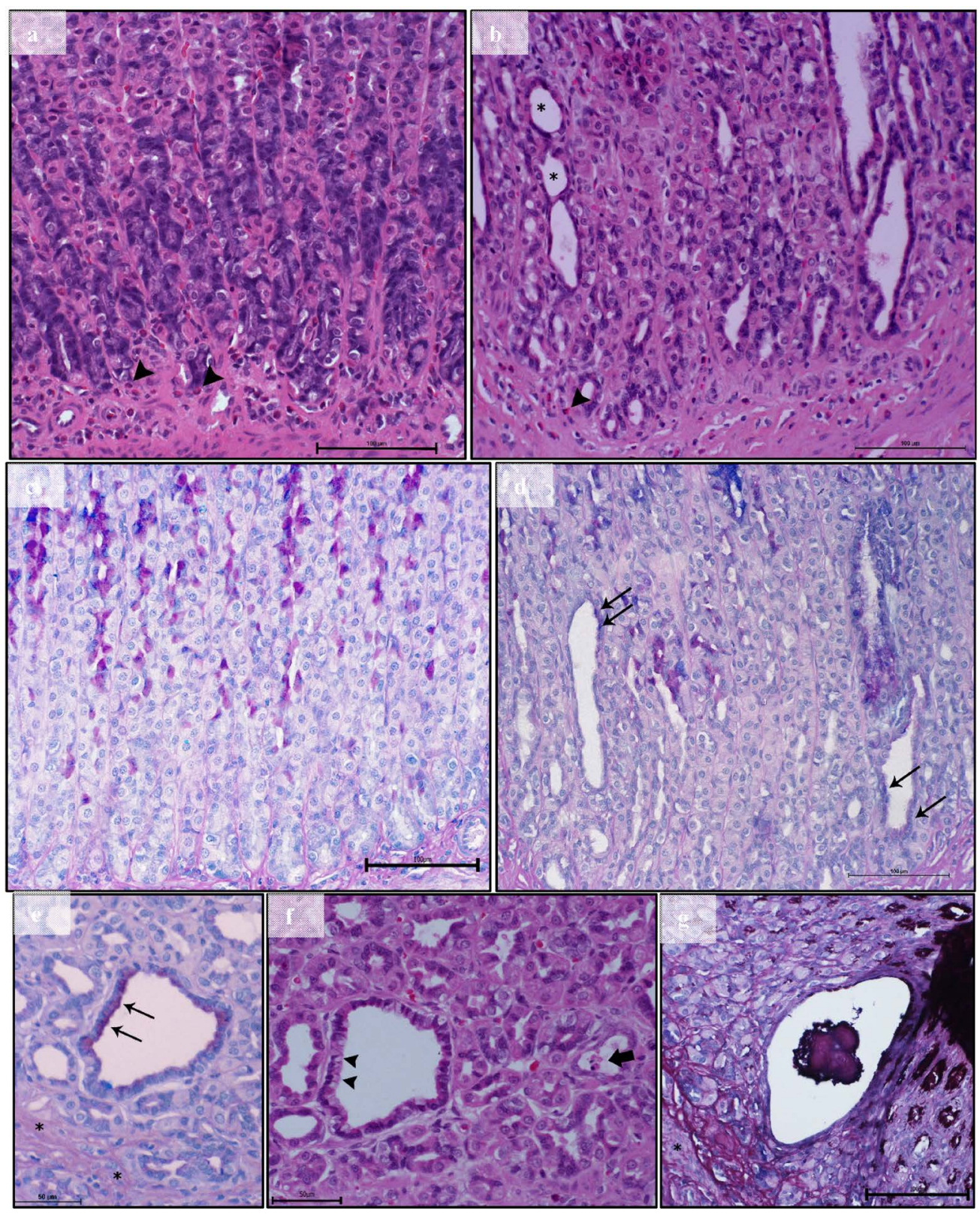

Figure 2. Gastric glands of the rat stomach (fundus) from rats fed a 60\% GM or non-GM corn diet. Photomicrographs of H\&E stained sections of the gastric glands: (a) from a non-GM-fed rat showing normal gland appearance, and (b) from a GM-fed rat showing large gland dilatations with epithelial cell elongation $\left.{ }^{*}\right)$. In both sections, several granular leukocytes can be seen deep to the gastric glands (arrowheads). Photomicrographs of AB/PAS stained sections: (c) from a non-GM-fed rat showing normal gland appearance, and (d) from a GM-fed rat showing altered staining properties of the epithelium of the gland dilatations (arrows). Photomicrographs (b) and (d) are corresponding sections from the same GM-fed rat. Corresponding photomicrographs of gland dilatation in the same GM-fed rat stained with: (e) AB/PAS and (f) H\&E. The AB/PAS-stained section shows PAS-positive stained cells in a deeply situated gland dilatation. Note the smooth muscle fibres ${ }^{*}$ ) of the muscularis mucosa slightly deep to the gland. Cells with such intense PAS staining are characteristic of the mucus-producing cells of the gastric pits and not the deep gland region. The corresponding H\&E-stained section of gland dilatations shows cuboidal cells with a lucid apical cytoplasm (arrowheads), as well as cellular debris in the lumen of another gland (thick arrow). Scale bar $=50 \mu \mathrm{m}$. (g) Photomicrograph of an $\mathrm{AB} / \mathrm{PAS}$ stained section showing a grossly enlarged glandular cyst in the mucosa of a GM-fed rat. The dilatation nearly spans the full depth of the mucosa. Note the smooth muscle fibres $\left(^{*}\right)$ of the muscularis mucosa slightly deep to the gland and the intensely purple staining cells of the gastric pits (large arrowheads). The epithelium lining the dilated gland appears elongated and the gland contains PAS-positive debris or mucus. Image is a combined $\mathrm{z}$-stack. Scale bar $=100 \mu \mathrm{m}$. 
the lamina propria below the glandular region showed no significant difference between the two groups (Table 2).

Gland dilatations or cysts were seen in several animals of both groups (6/10 in GM-fed rats; 4/10 non-GM-fed rats; Table 3). The dilatations were often observed near the glandular/non-glandular stomach junction. In the non-GM-fed rats, the gland dilatations were small and the lining cells were most often cuboidal or columnar in shape. In the GM-fed group, the dilatations were large, with some of the lining cells elongated or stained intensely with PAS (dark pink) or $\mathrm{AB} / \mathrm{PAS}$ (dark purple). In some corresponding H\&E-stained sections, these cells had a lucid apical cytoplasm. The staining properties of these cells resemble mucus-producing cells of the gastric pits, which suggest epithelial dysplasia and not intestinal metaplasia (Figure 2). In some of the GM-fed rats, the gland dilatations contained cellular debris or mucus (Figure 2(f) and Figure 2(g)). One GM-fed rat had a grossly enlarged glandular cyst that nearly spanned the full depth of the mucosa (Figure 2(g)). The epithelium lining this enlarged gland was attenuated and the gland lumen contained a large clump of PAS-positive debris or mucus. These staining features were only seen in the gland dilatations of the GM-fed rats, but this was not statistically significant in either the full-set or subset analyses (Table 3).

The number of rats showing gland dilatations with elongated epithelium in the GM-fed group was statistically significantly greater than rats fed the non-GM diet $(\mathrm{RR}>6.60, \mathrm{p}=0.011$; Table 3 ; please note that since none of the non-GM-fed rats exhibited this pathology, the $2 \times 2$ table had a zero in a cell. This generated an undefined relative risk (RR). Placing a 1 in that cell provided

Table 3. Number of rats with gland dilatations in the gastric glands of the fundus of rats fed a 60\% GM or non-GM corn diet.

\begin{tabular}{|c|c|c|c|c|c|c|c|}
\hline & \multicolumn{2}{|c|}{$\begin{array}{c}\text { GM } \\
\text { Outcome of Interest }\end{array}$} & \multicolumn{2}{|c|}{$\begin{array}{c}\text { Non-GM } \\
\text { Outcome of Interest }\end{array}$} & \multirow{2}{*}{ Relative Risk } & \multirow{2}{*}{$\begin{array}{l}\text { 95\% Confidence } \\
\text { Interval }\end{array}$} & \multirow{2}{*}{$\begin{array}{c}\text { Statistical } \\
\text { Significance } \\
(\mathrm{p}<0.050)^{\mathrm{a}}\end{array}$} \\
\hline & Present & Absent & Present & Absent & & & \\
\hline \multicolumn{8}{|c|}{ Analysis of all rats studied (GM-fed n = 10; non-GM-fed n = 10) } \\
\hline No. of rats with gland dilatations & 6 & 4 & 4 & 6 & 1.50 & $0.60-3.74$ & NS \\
\hline $\begin{array}{l}\text { No. of rats with gland dilatations that are lined } \\
\text { by cells exhibiting PAS or AB/PAS staining }\end{array}$ & 4 & 6 & 0 & 10 & $\begin{array}{l}\text { Undefined } \\
(>4.40)^{\mathrm{b}}\end{array}$ & $\begin{array}{l}\text { Undefined } \\
(0.59-33.07)^{\mathrm{b}}\end{array}$ & NS \\
\hline $\begin{array}{l}\text { No. of rats with gland dilatations that } \\
\text { are lined by elongated cells }\end{array}$ & 6 & 4 & 0 & 10 & $\begin{array}{l}\text { Undefined } \\
(>6.60)^{\mathrm{b}}\end{array}$ & $\begin{array}{c}\text { Undefined } \\
(0.95-45.74)^{\mathrm{b}}\end{array}$ & $0.011^{*}$ \\
\hline \multicolumn{8}{|c|}{ Subset analysis of only rats with gland dilatations (GM-fed $n=6$; non-GM-fed $n=4$ ) } \\
\hline $\begin{array}{l}\text { No. of rats with gland dilatations that are lined } \\
\text { by cells exhibiting PAS or AB/PAS staining }\end{array}$ & 4 & 2 & 0 & 4 & $\begin{array}{l}\text { Undefined. } \\
(>3.33)^{\mathrm{b}}\end{array}$ & $\begin{array}{c}\text { Undefined } \\
(0.53-21.03)^{\mathrm{b}}\end{array}$ & NS \\
\hline $\begin{array}{l}\text { No. of rats with gland dilatations } \\
\text { that are lined by elongated cells }\end{array}$ & 6 & 0 & 0 & 4 & $\begin{array}{l}\text { Undefined. } \\
(>4.29)^{\mathrm{b}}\end{array}$ & $\begin{array}{c}\text { Undefined } \\
(0.72-25.39)^{\mathrm{b}}\end{array}$ & $0.005^{* *}$ \\
\hline
\end{tabular}

aTwo-tailed Fisher's exact test. Statistical significance: ${ }^{*} \mathrm{p}<0.050$ to $0.010,{ }^{* *} \mathrm{p}<0.010$ to $0.001,{ }^{* * *} \mathrm{p}<0.001$. ${ }^{\mathrm{b}}$ Due to the presence of a zero in a cell, the relative risk and confidence intervals were calculated as being undefined. An approximation (underestimate) of these was obtained by putting " 1 " into the cell with the zero. This was only done for the relative risk and confidence interval. The p-value was calculated using the original, non-approximated data. Statistical significance: $\mathrm{p}<0.050$. 
an underestimate of the RR at 6.60, that is, the RR was greater than 6.60). A subset analysis of the data from only the rats that exhibited gland dilatations confirmed that rats on the GM diet always had at least one enlarged gland exhibiting an elongated epithelium, whilst the rats on the non-GM diet had none ( $\mathrm{p}=$ 0.0048; Table 3).

A scale of severity of the gland dilatations was also generated where the presence of a gland dilatation in the section was given a 1 and any subsequent observation (epithelial dysplasia or elongation) was given an extra 1 for each observation. The maximum number any animal could score was 3 . The results for each dietary group were averaged and this provided a gland dilatation severity score (Table 2). The severity score was higher in the GM-fed group (a median of 2.50) than in the non-GM-fed group (a median of 0.00 ), however this was not statistically significant.

\subsection{Immunohistochemistry}

In the fundus of the stomach, caspase 3 positive cells were sporadic, with some sections exhibiting only one or two cells labelled in the whole section, while others had intermittent areas with many labelled cells. Therefore, an overall apoptotic count was not possible to attain without sampling bias. As a result, a scale of $0-4$ was generated to assess the frequency of cells labelled: $0=$ no cells labelled, $1=$ one to a few cells labelled, $2=$ few to several cells labelled, $3=$ several cells labelled, and $4=$ many cells labelled in the whole section. Each animal was given a score and an average was generated per feeding group (Table 4). Labelling for caspase 3 was rarely seen in any of the gland dilatations of either feeding group.

The anti-Ki67 labelling was seen primarily at the base of the gastric pits of the GM-fed and non-GM-fed groups. There was a significant $21 \%$ reduction ( $\mathrm{p}=$ 0.028 ) in the proportion of nuclei that were labelled with Ki67 antibody in the GM-fed group compared with the non-GM-fed group (Table 4). In addition, a significant decrease of $31 \%(\mathrm{p}=0.033)$ was seen in the number of proliferating cells per pit + gland depth in the GM-fed group (Table 4).

Some animals in both groups had a wider distribution of Ki67 labelling in the distal pit and proximal glandular regions (Figure 1). A score to assess the spread was generated: 1 = few cells labelled in the neck region; 2 = compact spread; $3=$ medium-compact spread; $4=$ medium spread. A higher spread would indicate a more actively dividing mucosal epithelium. Results showed that on average, both groups had the same spread of dividing cells in the neck region (Table 4).

Some animals in both groups had sporadic labelling in the gastric glands. These animals were given a score of $1=$ present, and animals which had none or hardly any labelling in the gastric glands were given a score of $0=$ absent. Six out of 10 non-GM-fed rats and nine out of $10 \mathrm{GM}$-fed rats had such labelling. One non-GM-fed rat had many labelled nuclei in the gastric gland region. The score for the presence of labelling in the gastric glands was added to the gland dilatations severity score, which resulted in a 6 times higher score in the GM-fed 
Table 4. Apoptotic and dividing cells in the stomach (fundus) mucosa of rats fed a 60\% GM or non-GM corn diet.

\begin{tabular}{|c|c|c|c|c|c|c|c|c|}
\hline & \multicolumn{3}{|c|}{ GM } & \multicolumn{3}{|c|}{ Non-GM } & \multirow{2}{*}{$\begin{array}{l}\text { Statistical } \\
\text { Significance } \\
(\mathrm{p}<0.050)^{\mathrm{b}}\end{array}$} & \multirow{2}{*}{$\begin{array}{c}\text { Percentage } \\
\text { Change }(\%)^{c}\end{array}$} \\
\hline & $\begin{array}{l}\text { Mean or } \\
\text { median }^{\mathrm{a}}\end{array}$ & $\mathrm{SD}$ or $\mathrm{IQR}^{\mathrm{a}}$ & $\mathrm{n}$ & $\begin{array}{l}\text { Mean or } \\
\text { median }^{\mathrm{a}}\end{array}$ & $\mathrm{SD}$ or $\mathrm{IQR}^{\mathrm{a}}$ & $\mathrm{n}$ & & \\
\hline $\begin{array}{l}\text { Frequency of apoptotic cells } \\
\text { in the gastric mucosa }\end{array}$ & 1.00 & $1.00-2.25$ & 8 & 1.50 & $1.00-2.25$ & 8 & NS & -33.33 \\
\hline$\%$ dividing cells/total count & 10.07 & 1.43 & 10 & 12.75 & 3.09 & 10 & $0.028^{*}$ & -21.02 \\
\hline Dividing cells/pit + gland depth & 0.18 & 0.05 & 10 & 0.26 & 0.09 & 10 & $0.033^{*}$ & -30.77 \\
\hline $\begin{array}{c}\text { Spread of dividing cells in the } \\
\text { neck region }\end{array}$ & 3.00 & $2.25-3.00$ & 10 & 3.00 & $2.00-3.00$ & 10 & NS & 0 \\
\hline $\begin{array}{c}\text { Presence of dividing cells in } \\
\text { gastric glands + gland dilatation } \\
\text { severity score }\end{array}$ & 6.00 & $1.00-7.00$ & 10 & 1.00 & $0.25-2.75$ & 10 & NS & 600.00 \\
\hline
\end{tabular}

${ }^{\mathrm{a}}$ For non-normally distributed data, the median and interquartile range (IQR) are given. $\mathrm{SD}=$ standard deviation. ${ }^{\mathrm{b}}$ Statistical significance: ${ }^{*} \mathrm{p}<0.050$ to $0.010,{ }^{* *} \mathrm{p}<0.010$ to $0.001,{ }^{* *} \mathrm{p}<0.001$. The effect of the GM diet compared with the non-GM diet as a percentage change. The means were compared, unless one or both variables were not normally distributed, when the medians were compared. A negative sign before the number indicates that the GM diet decreased the variable. No sign indicates that the GM diet increased the value of the variable.

group than in the non-GM-fed group (Table 4); however, this was not statistically significant.

\subsection{Electron Microscopy}

Transmission electron microscopic investigations of the fundic region of the stomach demonstrated a significant loss $(\mathrm{p}=0.006)$ of tight junction apposition between the mucus-producing cells of the gastric surface and pits of the GM-fed animals (Table 5 and Table 6; Figure 3). The non-GM-fed rats commonly had well-apposed tight junctions ( $44 \%$ of these rats). In contrast, the GM-fed rats commonly had poorly-apposed tight junctions. The number of poorly-apposed tight junctions per rat was 3.5 times higher in GM-fed rats $(p=0.006$; Table 5). When expressed as the percentage of poorly-apposed tight junctions per total count, GM-fed rats were almost 5 times higher than non-GM fed rats $(\mathrm{p}=0.004$; Table 5). Every GM-fed rat had at least one poorly-apposed tight junction and the relative risk (RR) of a rat having at least one poorly-apposed tight junction was almost twice as high in GM-fed rats compared with non-GM-fed rats ( $p=$ 0.033; Table 6).

Furthermore, $70 \%$ of GM-fed rats had more than $30 \%$ of their tight junctions poorly-apposed ( $\mathrm{p}=0.003$; Table 6 ) compared with none of the GM-fed rats. The RR of a rat having $30 \%$ of its tight junctions poorly apposed was over 7 times higher in rats fed the GM-corn diet compared with rats fed the non-GM-corn diet $(\mathrm{p}=0.003$; Table 6$)$. Although not statistically significant, $20 \%$ of the GM-fed rats had more than $50 \%$ of their tight junctions poorly-apposed compared with none in the non-GM-fed rats. The apposition loss was seen as either a partial or a complete loss, or as blebbing (Figure 3(d) and Figure 3(e)). 
Table 5. Transmission electron microscopic investigation of tight junctions in the stomachs of rats fed a $60 \%$ GM or non-GM corn diet.

\begin{tabular}{|c|c|c|c|c|c|c|c|c|}
\hline & \multicolumn{3}{|c|}{ GM } & \multicolumn{3}{|c|}{ Non-GM } & \multirow{2}{*}{$\begin{array}{l}\text { Statistical } \\
\text { Significance } \\
(\mathrm{p}<0.050)^{\mathrm{b}}\end{array}$} & \multirow{2}{*}{$\begin{array}{l}\text { Percentage } \\
\text { Change }(\%)^{\circ}\end{array}$} \\
\hline & Median & $\mathrm{IQR}^{\mathrm{a}}$ & $\mathrm{n}$ & Median & $\mathrm{IQR}^{\mathrm{a}}$ & $\mathrm{n}$ & & \\
\hline $\begin{array}{l}\text { No. of poorly apposed } \\
\text { tight junctions per rat }\end{array}$ & 3.50 & $3.00-4.00$ & 10 & 1.00 & $0.00-2.00$ & 9 & $0.006^{\star *}$ & 350.00 \\
\hline $\begin{array}{l}\% \text { poorly apposed tight } \\
\text { junctions per total count }\end{array}$ & 35.42 & $24.17-44.44$ & 10 & 7.14 & $0.00-26.09$ & 9 & $0.004^{\star *}$ & 496.08 \\
\hline
\end{tabular}

${ }^{\mathrm{a}} \mathrm{IQR}=$ interquartile range. ${ }^{\mathrm{b}}$ Statistical significance: ${ }^{*} \mathrm{p}<0.050$ to $0.010,{ }^{* *} \mathrm{p}<0.010$ to $0.001,{ }^{* * *} \mathrm{p}<0.001$. ${ }^{\mathrm{c}}$ Calculated Percentage Change of the effect of eating the GM diet compared with the non-GM diet. ${ }^{\mathrm{d} N u m b e r}$ of poorly apposed tight junctions as a percentage of the total number of tight junctions counted.

Table 6. Number of rats with poorly-apposed tight junctions between the mucus-producing cells of the gastric surface and pits of rats fed a $60 \%$ GM or non-GM corn diet.

\begin{tabular}{|c|c|c|c|c|c|c|c|}
\hline & \multicolumn{2}{|c|}{$\begin{array}{c}\text { GM } \\
\text { Outcome of Interest }\end{array}$} & \multicolumn{2}{|c|}{$\begin{array}{c}\text { Non-GM } \\
\text { Outcome of Interest }\end{array}$} & \multirow{2}{*}{$\begin{array}{l}\text { Relative } \\
\text { Risk }\end{array}$} & \multirow{2}{*}{$\begin{array}{l}\text { 95\% Confidence } \\
\text { Interval }\end{array}$} & \multirow{2}{*}{$\begin{array}{c}\text { Statistical } \\
\text { Significance } \\
(\mathrm{p}<0.050)^{2}\end{array}$} \\
\hline & Present & Absent & Present & Absent & & & \\
\hline No. of rats with poorly apposed tight junctions & 10 & 0 & 5 & 4 & 1.80 & $1.00-3.23$ & $0.033^{*}$ \\
\hline $\begin{array}{l}\text { No. of rats with at least } 30 \% \text { of their } \\
\text { tight junctions poorly apposed }\end{array}$ & 7 & 3 & 0 & 9 & $\begin{array}{l}\text { Undefined } \\
(>7.00)^{\mathrm{b}}\end{array}$ & $\begin{array}{l}\text { Undefined } \\
(1.04-46.95)^{\mathrm{b}}\end{array}$ & $0.003^{* *}$ \\
\hline $\begin{array}{l}\text { No. of rats with at least } 50 \% \text { of their } \\
\text { tight junctions poorly apposed }\end{array}$ & 2 & 8 & 0 & 9 & $\begin{array}{l}\text { Undefined } \\
(>2.00)^{\mathrm{b}}\end{array}$ & $\begin{array}{l}\text { Undefined } \\
(0.21-18.69)^{\mathrm{b}}\end{array}$ & NS \\
\hline
\end{tabular}

${ }^{a}$ Statistical analysis by Fisher's Exact test. Statistical significance: ${ }^{*} \mathrm{p}<0.050$ to $0.010,{ }^{* *} \mathrm{p}<0.010$ to $0.001,{ }^{* * *} \mathrm{p}<0.001$. ${ }^{\mathrm{b}} \mathrm{Due}$ to the presence of a zero in a cell, the relative risk and confidence intervals were calculated as being undefined. An approximation (underestimate) of these was obtained by putting "1" into the cell with the zero. This was only done for the relative risk and confidence interval. The p-value was calculated using the original, non-approximated data. Statistical significance: $\mathrm{p}<0.050$.

\subsection{Severity Score}

A severity score was developed that joined together all the adverse findings into a single score for each rat. Observations that were considered to be adverse included: the spread of Ki67 labelling in the neck region of the gastric mucosa (a 1 4 scale for neck region spread), the presence of Ki67 labelling in the gastric glands $(0=$ absent; or $1=$ present $)$, the frequency of caspase 3 labelling in the gastric mucosa of the whole tissue sample (a 0 - 4 scale for the presence of labelled cells), gland dilatations plus their staining properties and morphological alterations to their lining epithelium (a 0 - 3 score of gland dilatation severity), and whether a rat had $30 \%$ of their tight junctions poorly apposed $(0=$ no; or $1=$ yes). The highest severity score possible was 13 , which would indicate that a rat had been severely affected by the diet. Rats on the GM diet had a severity score that was $33 \%$ higher than rats on the non-GM diet $(7.30 \pm 1.42$ vs $5.50 \pm 1.90$ for GM-fed and non-GM-fed respectively; $\mathrm{p}=0.027$ ).

\section{Discussion}

The present study assessed the effects of long term-feeding of a $60 \%$ corn diet on the histopathology of the rat stomach. 

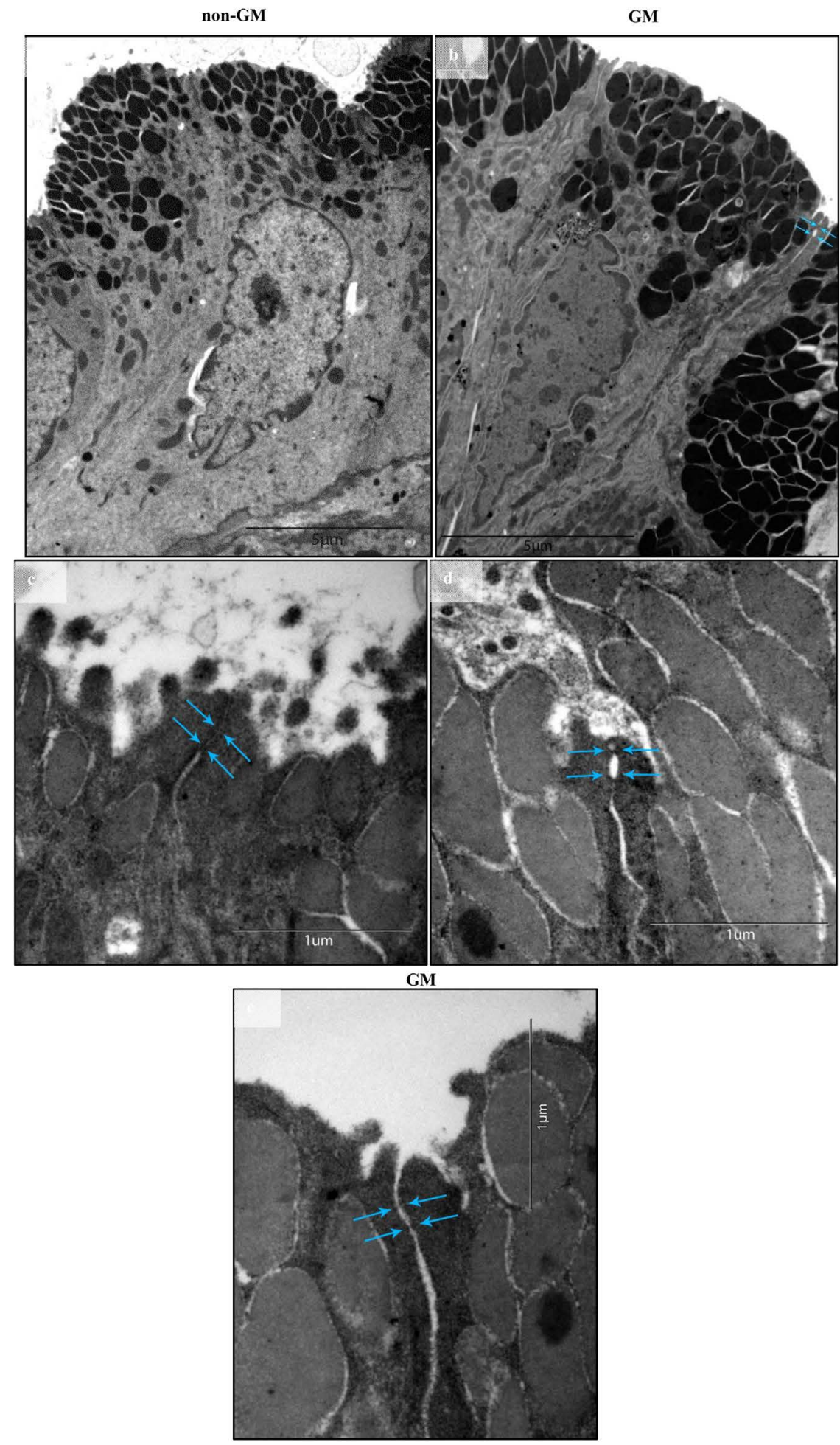

Figure 3. Transmission electron micrographs of mucus-producing cells of the pit and surface of stomachs from rats fed a $60 \%$ GM or non-GM corn diet. Ultramicrographs of mucus-producing cells at low magnification in: (a) non-GM-fed rats, and (b) GM-fed rats. In the ultramicrograph of the GM-fed rat (b), poorly-apposed tight junctions are visible on either side of the epithelial cell. In particular, the tight junction on the right, which shows blebbing (arrows). Scale bar $5 \mu \mathrm{m}$. (c) At higher magnification, the well-apposed tight junction (arrows) in a non-GM-fed rat has clearly visible plaque and no gap between apposing leaflets, while the poorly apposed tight junctions in GM-fed rats are seen as: (d) blebbing or (e) complete loss of tight junction apposition (arrows). Scale bar $1 \mu \mathrm{m}$. 
Initially, the dietary intake of both groups of rats was not as high as expected and GM-fed rats were eating less than non-GM-fed rats. Neither group of rats lost weight. The diets were therefore sent for repelleting to increase the moisture content slightly, starting with the GM diet, because they were the most affected group. The provision of moister diets resulted in a typical weight gain [49] for the remainder of the study. Because the GM-fed rats were fed moister diets a few weeks before non-GM-fed rats, they weighed more at the end of the study than non-GM-fed rats. As a result, it is important to note the following. First, histological investigation of the non-glandular stomach did not demonstrate any pathognomonic sign of starvation, such as the thickening of the keratinized layer (Table 2) [50], confirming dietary and body weight observations that rats were not starved.

Second, due to the initial reduced dietary intake, GM-fed rats consumed less GM corn over the course of the experiment than predicted. Consequently, any adverse effects produced by GM corn on the stomach would have been lessened in this study. Third, the GM-fed rats started to eat moister diets and started to increase their dietary intake several weeks before the non-GM-fed rats. Therefore, GM-fed rats weighed more (and hence may have been better nourished) at the end of the study than non-GM-fed rats. This may have caused a confounder which biased the results towards GM-fed rats having better stomach health and fewer adverse findings than non-GM-fed rats.

As a result, the effects of the GM crop on the health of the rat stomach mucosa are likely to be under-reported in this study, and statistical tests comparing the GM-fed group to the non-GM-fed group are likely biased to find no difference between the groups (often described as "a bias to the null"). The study is therefore conservative in its findings and a repeat of the study may find an increase in adverse effects.

\subsection{Tight Junction Apposition Loss}

In the present study, the most striking difference was the loss in tight junction apposition between mucus-producing cells of the fundus in the GM-fed group, which was five times higher than in the non-GM-fed group $(p=0.004)$. Almost twice as many GM-fed rats had poorly apposed tight junctions as non-GM-fed rats $(\mathrm{RR}=1.80 ; \mathrm{p}=0.033)$. Every GM-fed rat had at least one poorly-apposed tight junction. The apposition loss was seen as a blebbing or a complete separation of the two leaflets (Figure 3). These structural changes are commonly associated with chemical gastropathy or bacterial infection [51] [52] [53]. However, bacterial infections are typically accompanied by inflammation, while chemical gastropathy is limited to mild or no inflammation [54]. The lack of a severe inflammatory response in the current study therefore suggests that the observed changes in the tight junctions in the GM-fed group may be a sign of chemical gastropathy. Chemical gastropathy (or reactive gastritis) occurs when there are surface-damaging agents such as chemical irritants or certain medications/drugs 
in the gastric lumen [38] [55]. In chemical gastropathy, the pathological changes are subtle, but are characterised by pit hyperplasia, mucus depletion, superficial oedema [38], with the absence of severe inflammation, atrophy, metaplasia, ulcers and polyps [55]. In severe cases, it is characterised by an increase in glandular depth and pit coiling [38] [54]. Although not statistically significant, the GM-fed group demonstrated a slight increase in mucosal thickness $(3.34 \%$ greater), particularly in the glandular depth $(2.11 \%$ greater than the non-GM group). Pit depth was also greater in the GM-fed group, but pit coiling was not observed. The absence of pit coiling in GM-fed rats may indicate that the effect is mild rather than severe. Alternatively, pit coiling may be a feature seen only in human stomachs.

A loss of tight junction apposition may result in a compromised mucosal barrier that may in turn result in the stomach wall becoming permeable to bacteria, viruses or macromolecules such as allergy-inducing proteins. The absence of a local inflammatory response in the stomach of these rats suggests that the loss of tight junction apposition was not sufficient to allow pathogens through the mucosal barrier to cause serious damage of underlying tissue and consequently trigger a local inflammatory response [56]. The permeability of the mucosal barrier is also determined by the presence of the basement membrane (which acts as a selective chemical barrier) and the mucous layer protecting the mucosal surface of the stomach [57]. Therefore any organism or substance would have to also breach these barrier components [58]. Future studies could investigate whether the stomach from a GM-fed rat has increased permeability by investigating the transepithelial electrical resistance of the mucosa [59].

In addition, the observed ultrastructural changes to the tight junctions between the mucus-producing cells may not result in a change in tight junction permeability. Tight junctions are composed of transmembrane proteins, occludin, claudins, and junctional adhesion molecules (JAMs), which are anchored to the cell cytoskeleton via cytosolic plaque proteins called the zonula occludens proteins (ZO-1, ZO-2, and ZO-3) [60] [61]. Each tight junction protein has a specific function or acts collectively with other tight junction proteins to regulate paracellular permeability, transepithelial migration of leukocytes, and to keep cells polar [62] [63] [64] [65]. The specific role of each individual tight junction protein is still being elucidated and new proteins are still being discovered. However, it is known that any change in the proteins of the tight junction may alter one function leaving others unaffected. For example, in an in vitro study, an induced mutation of one of the tight junction proteins (occludin) caused inhibition of neutrophil migration, but no change in the selective paracellular permeability or transepithelial electrical resistance of the epithelium [59]. In other words, the consequence of tight junction apposition loss observed in our study is dependent on which protein is affected.

The reorganisation of the tight junction proteins has been reported to be triggered by cytokines or apoptosis, through the reorganisation or contraction of the 
actin cytoskeleton [66] [67]. Apoptosis was scarcely seen in the gastric pits in most of the rats in our study. Therefore, it is possible that cytokines may be the cause.

\subsection{Decrease in Proliferative Cells}

An overall decrease in mitotic cells was seen in the stomach mucosa of GM-fed animals $(20.02 \%$ less than non-GM; $p=0.028)$. However, a semi-quantitative analysis of proliferation in the neck region as well as the presence of labelling in the gastric glands did not reveal any differences between groups. Therefore, the potential role of this observation and the effect of the GM diet is unclear. An additional measure of parietal and enterochromaffin-like cell (ECL) populations may give a more complete interpretation [55].

\subsection{The Cry Proteins as a Source of Rodent Toxicity}

The action of the Cry proteins on gut tissue is claimed to be specific to certain insects and safe for mammalian consumption [68]. However, histopathological or immunotoxicological studies on the effects of the proteins on animal physiology are scarce [30], particularly of the Cry proteins produced by GM crops [13], which are encoded by cry genes that have been modified, enhanced or synthetically produced [2]. The species-specific mode of action of Cry proteins are believed to be based on three things: 1) the insects' mid-gut proteases which cleave the Cry proteins, consequently activating the proteins by exposing their binding site [28]; 2) the activated proteins binding to the insects' specific cadherin receptor [69]; and 3) the Cry proteins binding to the insects' specific cell membrane receptor(s) [70] [71]. It should, however, be noted that the genes encoding for the Cry proteins in GM crops have been changed, that is, they have had alterations made to the nucleotide sequence and/or are truncated [2] [72], which may have altered their species specificity.

The GM crops that express Cry proteins are commonly referred to as Bt crops. In general, they contain truncated genes which encode for the active toxins rather than the inactivated crystalline protoxins produced by the bacterium, Bacillus thuringiensis [2]. The reason for this is that the genes coding for the full toxin do not provide the plant with adequate insecticidal strength [72]. Therefore, the Cry proteins produced by the Bt crops may have been changed in such a way that impacts their specificity and thus makes them capable of interacting with epithelial cells of the non-target mammalian gut.

An in vitro study on bovine intestinal cells [73] found that the CrylAb protein binds to the apical surface of enterocytes. Specifically, the protein was bound to actin, a major protein of the cytoskeleton. It has been shown that actin's interaction with tight junction proteins may have an effect on tight junction integrity [66] [74]. Our present study reported ultrastructural changes to the tight junctions in the form of blebbing or complete separation of the two leaflets (Figure 3). These could have occurred as a result of the binding of one or both of the Cry 
proteins to actin. While reference [73] proposed that the interaction of Cry1 Ab with actin would only occur in vitro because actin would not be exposed for binding in vivo; other studies have demonstrated that Cry proteins do bind to mammalian intestinal epithelium in in vivo and in situ [30] [75].

\subsection{Other Observed Changes}

One rat in the non-GM-fed group had a grossly enlarged squamous cyst in the non-glandular stomach, which is a common and not clinically significant occurrence in this strain of rats [76].

In some of the GM-fed rats, gland dilatations with epithelial elongation were observed in the glandular stomach $(\mathrm{p}=0.011$; Table 3$)$. Gland dilatations are a natural occurrence, particularly in aged rats [77]. However, they have also been observed in association with certain diseases or pathological conditions [77] [78] [79] [80]. In the current study, both the GM-fed rats and the non-GM-fed rats had gland dilatations. However, in the GM-fed rats, some of the gland dilatations were lined by attenuated epithelial cells or with an epithelium of altered staining properties suggestive of epithelial dysplasia (Table 3 and Figure 2). These observations were not found in any of the non-GM-fed rats. Therefore, these changes to the epithelium of the gland dilatations are likely to be an effect of the GM diet.

The gland dilatations were often seen at the junctional region between the non-glandular and glandular stomach areas. The non-glandular stomach is a compartment where ingested products reside for a longer period [81]. If the GM diet has a toxic component, the effects are more likely to be observed in the junctional region of the glandular stomach, because of the prolonged holding of the feed in that compartment. In the non-glandular stomach, adverse changes are not likely to be seen due to the protective function of the keratinized layer in that part of the stomach.

The elongation of epithelial cells seen in the gland dilatations in GM-fed rats could indicate either that the gland is congested or that the glandular epithelium is undergoing repair. If glandular congestion was the cause of epithelial elongation, a high frequency of debris or mucus plugs would be expected in the glands. However, only a few of the GM-fed rats had cellular debris or mucus in their gland dilatations (Figure 2(f) and Figure 2(g)). Therefore, glandular congestion is unlikely to be the cause of epithelial elongation in the dilated glands.

Alternatively, elongation of epithelial cells in the gut mucosa could reflect a rapid repair mechanism called restitution, which occurs following an insult to the mucosal surface epithelium [57]. The mechanism involves the elongation of the remaining viable cells to cover the basal lamina to maintain mucosal barrier integrity and continuity until other mechanisms ensue, such as cellular proliferation and/or an extensive inflammatory response [58]. Restitution is most often seen at the liminal surface and in the pits [82]. However, if the epithelium of the gastric glands is damaged, this same mechanism of repair may occur to ensure 
that the basal lamina is not breached. Cellular debris in gland dilatations was seen in some of the GM-fed rats, which provides further evidence that this may be occurring.

Another abnormality observed in the gland dilatations was epithelial dysplasia. Although not statistically significant, this feature was only seen in the gland dilatations of the GM-fed group and was not seen in the non-GM-fed group. This type of change to the staining properties of the epithelial cells could indicate the presence of immature cells that had migrated from the proliferative zone. Injury can alter the differentiation of cells from the proliferative zone, that is, it can change stomach cell lineages [78] and thus alter the staining-properties of the gastric gland cells. Non-steroidal anti-inflammatory drugs, ethanol and Helicobacter pylori infection have been known to cause damage/changes to the stomach proliferative zone and consequently initiate the migration of immature cells [78]. The method of regeneration following such damage is still poorly understood, however immunohistochemistry for certain progenitor cell markers and metaplasia can better reveal the nature of the change. In particular, the markers for proliferating cell nuclear antigen (PCNA), doublecortin and calcium/calmodulin-dependent protein kinase-like-1 (DCAMKL1), spasmolytic polypeptide-expressing metaplasia (SPEM), and trefoil family factor 2 (TFF2) may further help to interpret the finding [78].

Alternatively, the presence of immature cells, with altered staining properties, along with cystic gland dilatations may be a sign of ulcer healing or gastric epithelial dysplasia [78]. Ulcer healing is characterised by the predominant presence of mucous-like cells in the gastric glands and neck regions [78]. According to the stage of healing, it may also be accompanied by an increase in mucosal connective tissue, and a decrease in mucosal thickness [80]. In the present study, cells with altered staining properties were observed in the glands, but there was no accompanying increase in mucosal connective tissue or a decrease in mucosal thickness. Immunohistochemistry for markers of progenitor cells, in particular the distribution of TFF2, DCAMK1 and PCNA-labelled cells, can better determine whether ulcer healing or gastric epithelial dysplasia is occurring [78].

Gastric epithelial dysplasia is a pre-neoplastic condition [78] [83] that is associated with an increase in proliferation of epithelial cells and an abnormal distribution of such cells in the gastric mucosa. In addition, there is an impairment of apoptosis [83]. In the present study, the frequency and number of apoptotic cells in both groups was approximately the same and an increase in proliferative cells was not observed (Table 4). In fact, a decrease in proliferation was seen ( $20 \%$ less than non-GM; $\mathrm{p}=0.028$ ). Therefore, gastric epithelial dysplasia is unlikely to be the cause of the presence of immature cells and gland dilatations. However, immunohistochemistry for markers of progenitor cells can better evaluate this, in particular TFF2, DCAMK1, PCNA, and SPEM [78].

\subsection{The Need for Histopathological Studies}

Our present findings demonstrate changes to the stomach morphology of rats 
fed a $60 \%$ GM corn diet. These changes were discovered through quantitative analyses and the use of special stains (e.g. AB/PAS), immunohistochemical techniques and TEM. Previous studies investigating the effects of GM crops on rat health most often do not utilize these or other similar methods [13]. In fact, many of the published studies appear to be qualitative, containing very little if any morphometric analyses or cell counts. In addition, the publications are so brief in their methods and results sections that it is very hard to determine the nature of their histological examinations. Often, the authors have a short histology methods section, which in brief states that tissues were collected, processed and embedded in wax, stained with $H \& E$ and a pathologist or veterinary pathologist performed the histopathological analysis [84]-[89]. They do not mention what these analyses entailed, for example what parameters were regarded as pathological or what was measured and why.

In contrast, in the investigations of the effect of novel compounds or treatments on the gastrointestinal tract, such as chemotherapy-induced mucositis, gastric biopsies, or the effect of early weaning on the health of the digestive tract of neonatal pigs, the analytical methods are detailed and specific [55] [90]-[95]. Such publications contain detailed lists of the changes that need to be investigated and the microscopic techniques and morphometric analyses that need to be used. For example, mitosis, apoptosis and autophagy are known to be good indicators of mucosal regeneration in the small intestine following injury. Therefore, immunohistochemistry with in-tissue cytometry looking at the expression of markers for mitosis (Ki67), apoptosis (caspase 3) and autophagy (MAP I LC3) have been used to assess mucosal regeneration after early weaning of piglets [90]. In mucositis-induced models, the investigation of the degree of damage not only regularly requires detailed quantitative histological analyses to be conducted, but also immunohistochemistry for markers of apoptosis (caspase $3)$, cell proliferation (BrdU), and pro-inflammatory cytokines (such as TNF, IL-1 $\beta$ and IL-6) [91] [92] [95]. Such rigorous analyses allow for a more thorough and precise assessment of possible pathological changes, while at the same time decreasing the chance of subtle changes being overlooked [13].

In other words, a general histological investigation would normally contain morphometric analyses as well as cell counts. A thorough general histological investigation would also normally include special stains and immunohistochemistry. For example, staining the tissue with AB/PAS to better identify the type of mucus being produced by the tissue, Masson's trichrome to better assess the amount of connective tissue fibres in the tissue, or labelling the tissue with antibodies for proliferation (Ki67 or BrdU) and apoptosis (caspase 3). A further morphological investigation utilising electron microscopy would also add to the thorough nature of the study, and may discover as yet unknown effects of GM crops or their protein products, since TEM evaluations are rare in this field [13].

However, the published studies of animal feeding of GM crops fall short of this norm, by most often determining their safety of GM crop consumption based on qualitative assessments [13]. For example, reference [84] in their pub- 
lished study of the general assessment of long-term effects of GM corn feed on rat health, did not provide evidence of morphometric analyses having been performed, stated that a board-certified veterinary pathologist examined the tissue, and concluded with a statement that "since no meaningful differences were observed, no further microscopic examinations were deemed necessary" [84]. In addition, studies by references [86] and [96] observed gastric gland dilatations in both the GM and non-GM-fed groups. However, because the dilatations were observed in both groups, the authors deemed them not to be diet related and no further investigations were made.

In contrast, our study has shown that further analyses are necessary to elaborate certain findings. For example, similar to references [86] and [96], we found gland dilatations in both the GM-fed and non-GM-fed groups. However, we took further observations and found that only the GM-fed group had additional epithelial elongation or dysplasia in the affected glands (Table 3 and Figure 2). Had we not evaluated the gastric gland epithelium or stained our sections with $\mathrm{AB} / \mathrm{PAS}$, our statistically significant observation of epithelial elongation occurring in the gland dilatations of GM-fed rats only, would have gone unnoticed. In a different example, we found a decrease in cell proliferation in the gastric mucosa of the GM-fed rats compared with the non-GM fed rats (Table 4), which will require parietal and ECL cell population counts to properly assess the clinical implication of the decrease [55].

Another most striking observation was the loss of tight junction apposition in the GM-fed rats (Table 5 and Table 6). This was detected using TEM, which is a method rarely utilised in other GM feeding studies [13]. Morphologically, tight junction apposition loss can only be viewed using electron microscopy (TEM or freeze-fracture electron microscopy) [47] [97]. Molecularly, it can be assessed using immunohistochemistry, immuno-flourescence confocal microscopy or TEM with immuno-gold labelling for specific tight junction proteins [98] [99]. The functional impact of tight junction apposition loss on gut permeability can be assessed, for example using Ussing chambers [100] or sucrose breath tests [101], or tight junction permeability specifically can be assessed in the colon using TEM with ruthenium red staining [102].

Our investigation also pooled all adverse changes because each adverse change on its own may not have any clinical significance or implications, however when pooled together, a synergistic or potentiating effect of the diet on rat health may be revealed. The following adverse changes were therefore pooled: the spread of Ki67 labelling in the neck region of the gastric mucosa, the presence of Ki67 labelling in the gastric glands, the frequency of caspase 3 labelling in the gastric mucosa of the whole tissue sample, the gland dilatation severity score, and whether a rat had $30 \%$ of their tight junctions poorly apposed. Our study found that the GM-fed rats had a statistically significant greater score than the non-GM-fed animals $(p=0.027)$. Our data were not weighted in order to prevent the introduction of a bias. Further studies are required to determine the clinical significance of this result. 


\section{Conclusion}

The stomachs of rats fed a $60 \%$ triple stack GM-corn diet exhibited ultrastructural alterations to tight junction apposition in the mucus-producing cells as well as gland dilatations exhibiting abnormal changes to their lining epithelium. This suggests that the GM corn or one or both of the insecticidal Cry proteins may have had adverse effects on rat stomachs and that chemical gastropathy may be the model of toxicity.

\section{Acknowledgements}

H. Vlieger for his help in the feeding trial. Dr JI Haynes for her help with the feeding trial and histological interpretation of results. Assoc/Prof. S. Callanan, Dr M. MacAlister, and Dr J. Finnie for their help in identifying pathologies. A. Jones, M. Spillanie, and Y. Van Sebille for their contribution and work in the Pilot Study. Prof. J. Heinemann, Dr C. Clinch-Jones, and Dr J. Kumaratilake for reading drafts. Dr C. Brownlow, Dr C. Clinch-Jones and the Flinders University Animal Facility for their assistance in the animal feeding study and autopsies. C. Leigh and Histology Services, University of Adelaide for their assistance with the autopsies and processing of tissues. None of the authors has any affiliation with GM crop production, use or commercialisation entities. IZ was supported by the Australian Postgraduate Award. IHER's contribution was funded by a grant from the Government of Western Australia and donations from individuals. As per IHER's constitution, providers of funding cannot influence how the research is conducted.

\section{References}

[1] Clive, J. and Krattiger, A.F. (1996) Global Review of the Field Testing and Commercialization of Transgenic Plants, 1986 to 1995: The First Decade of Crop Biotechnology. ISAAA Briefs No. 1. ISAAA, Ithaca, 31.

[2] ISAAA (2017) ISAAA’s GM Approval Database. http://www.isaaa.org/gmapprovaldatabase/

[3] Wilson, A.K., Latham, J.R. and Steinbrecher, R.A. (2006) Transformation-Induced Mutations in Transgenic Plants: Analysis and Biosafety Implications. Biotechnology and Genetic Engineering Reviews, 23, 209-237. https://doi.org/10.1080/02648725.2006.10648085

[4] ISAAA (2016) Global Status of Commercialized Biotech/GM Crops: 2016. ISAAA Brief No. 52. ISAAA: Ithaca.

[5] USDA (2016) Adoption of Genetically Engineered Crops in the U.S. United States Department of Agriculture. https://www.ers.usda.gov/data-products/adoption-of-genetically-engineered-crops-i n-the-us.aspx

[6] FAO/WHO (2000) Safety Aspects of Genetically Modified Foods of Plant Origin. Report of a Joint FAO/WHO Expert Consultation on Foods Derived from Biotechnology (29 May-2 June, 2000), Geneva.

[7] FSANZ (2007) The Role of Animal Feeding Studies in the Safety Assessment of Genetically Modified Foods. Report of a Workshop Hosted by Food Standards Aus- 
tralia New Zealand (Friday 15th June 2007). FSANZ, Canberra.

[8] EFSA (2010) Scientific Opinion on Application (EFSA-GMO-CZ-2008-62) for the Placing on the Market of Insect Resistant and Herbicide Tolerant Genetically Modified Maize MON 89034 x 1507 x MON 88017 x 59122 and All Sub-Combinations of the Individual Events as Present in Its Segregating Progeny, for Food and Feed Uses, Import and Processing under Regulation (EC) No 1829/2003. Dow AgroSciences and Monsanto EFSA Journal, 8, 1737-1781.

[9] FSANZ (2016a) Food Derived from GM Plants Containing Stacked Genes. http://www.foodstandards.gov.au/consumer/gmfood/stackedgene/Pages/default.asp $\underline{x}$

[10] Implementing Regulation (EU) (2013) COMMISSION IMPLEMENTING REGULATION (EU) No 503/2013 of 3 April 2013 on Applications for Authorisation of Genetically Modified Food and Feed in Accordance with Regulation (EC) No 1829/2003 of the European Parliament and of the Council and amending Commission Regulations (EC) No 641/2004 and (EC) No 1981/2006. Official Journal of the European Union.

[11] Domingo, J.L. and Bordonaba, J.G. (2011) A Literature Review on the Safety Assessment of Genetically Modified Plants. Environment International, 37, 734-742. https://doi.org/10.1016/j.envint.2011.01.003

[12] Snell, C., Bernheim, A., Berge, J.B., Kuntz, M., Pascal, G., Paris, A. and Ricroch, A.E. (2012) Assessment of the Health Impact of GM Plant Diets in Long-Term and Multigenerational Animal Feeding Trials: A literature Review. Food and Chemical Toxicology, 50, 1134-1148. https://doi.org/10.1016/j.fct.2011.11.048

[13] Zdziarski, I.M., Edwards, J.W., Carman, J.A. and Haynes, J.I. (2014) GM Crops and the Rat Digestive Tract: A Critical Review. Environment International, 73, 423-433. https://doi.org/10.1016/j.envint.2014.08.018

[14] Carman, J.A. (2004) Is GM Food Safe to Eat? In: Hindmarsh, R. and Lawrence, G., Eds., Recoding Nature Critical Perspectives on Genetic Engineering, UNSW Press, Sydney, 82-93.

[15] Custodio, M.G., Powers, W.J., Huff-Lonergan, E., Faust, M.A. and Stein, J. (2006) Growth, Pork Quality, and Excretion Characteristics of Pigs Fed Bt Corn or Non-Transgenic Corn. Canadian Journal of Animal Science, 86, 461-469. https://doi.org/10.4141/A05-082

[16] FSANZ (2016b) Current GM Applications and Approvals, Genetically Modified (GM) Foods. http://www.foodstandards.gov.au/consumer/gmfood/applications/Pages/default.asp $\underline{\mathrm{x}}$

[17] Hammond, B.G., Vicini, J.L., Hartnell, G.F., Naylor, M.W., Knight, C.D., Robinson, E.H., Fuchs, R.L. and Padgette, S.R. (1996) The Feeding Value of Soybeans Fed to Rats, Chickens, Catfish and Dairy Cattle Is Not Altered by Genetic Incorporation of Glyphosate Tolerance. The Journal of Nutrition, 126, 717-727. https://doi.org/10.1093/jn/126.3.717

[18] OECD (2008) OECD Guideline 452: Chronic Toxicity Studies, Guideline for the Testing of Chemicals. OECD, Paris.

[19] Fischer, A.H., Jacobson, K.A., Rose, J. and Zeller, R. (2008) Hematoxylin and Eosin Staining of Tissue and Cell Sections. CSH Protocols, 2008, pdbprot4986. https://doi.org/10.1101/pdb.prot4986

[20] Godlewski, M.M., Ślązak, P., Zabielski, R., Piastowska, A. and Garlak, M.A. (2006) Quantitative Study of Soybean-Induced Changes in Proliferation and Programmed 
Cell Death in the Intersinal Mucosa of Young Rats. Journal of Physiology and Pharmacology, 57, 125-133.

[21] Martinez-Puig, D., Manzanilla, E.G., Morales, J., Borda, E., Pérez, J.F., Piñeiro, C. and Chetrit, C. (2007) Dietary Nucleotide Supplementation Reduces Occurrence of Diarrhoea in Early Weaned Pigs. Livestock Science, 108, 276-279. https://doi.org/10.1016/j.livsci.2007.01.099

[22] Su, Y.-P., Tang, J.-M., Tang, Y. and Gao, H.-Y. (2005) Histological and Ultrastructural Changes Induced by Selenium in Early Experimental Gastric Carcinogenesis. World Journal of Gastroenterology, 11, 4457-4460. https://doi.org/10.3748/wjg.v11.i29.4457

[23] Zuo, T., Cao, L., Xue, C. and Tang, Q.-J. (2015) Dietary Squid Ink Polysaccharide Induces Goblet Cells to Protect Small Intestine from Chemotherapy Induced Injury. Food and Function, 6, 981-986. https://doi.org/10.1039/C4FO01191K

[24] Carman, J.A., Vlieger, H.R., Ver Steeg, L.J., Sneller, V.E., Robinson, G.W., Clinch-Jones, C.A., Haynes, J.I. and Edwards, J.W. (2013) A Long-Term Toxicology Study on Pigs Fed a Combined Genetically Modified (GM) Soy and GM Maize Diet. Journal of Organic Systems, 8, 38-54.

[25] Rausell, C., Munoz-Garay, C., Miranda-CassoLuengo, R., Gomez, I., Rudino-Pinera, E., Soberon, M. and Bravo, A. (2004) Tryptophan Spectroscopy Studies and Black Lipid Bilayer Analysis Indicate That the Oligomeric Structure of Cry1Ab Toxin from Bacillus thuringiensis Is the Membrane-Insertion Intermediate. Biochemistry, 43, 166-174. https://doi.org/10.1021/bi035527d

[26] Zhang, X., Candas, M., Griko, N.B., Taussig, R. and Bulla Jr., L.A. (2006) A Mechanism of Cell Death Involving an Adenylyl Cyclase/PKA Signaling Pathway Is Induced by the Cry1 Ab Toxin of Bacillus thuringiensis. Proceedings of the National Academy of Sciences of the United States of America, 103, 9897-9902. https://doi.org/10.1073/pnas.0604017103

[27] Zhang, X., Griko, N.B., Corona, S.K. and Bulla Jr., L.A. (2008) Enhanced Exocytosis of the Receptor BT-R(1) Induced by the CrylAb Toxin of Bacillus thuringiensis Directly Correlates to the Execution of Cell Death. Comparative Biochemistry and Physiology. Part B: Biochemistry and Molecular Biology, 149, 581-588. https://doi.org/10.1016/j.cbpb.2007.12.006

[28] Soberón, M., Pardo, L., Muñóz-Garay, C., Sánchez, J., Gómez, I., Porta, H. and Bravo, A. (2010) Pore Formation by Cry Toxins. In: Anderluh, G. and Lakey, J., Eds., Proteins. Membrane Binding and Pore Formation, Landes Bioscience and Springer Science+Business Media, Austin 127-142. https://doi.org/10.1007/978-1-4419-6327-7_11

[29] ANZFA (2000) Australia New Zealand Food Authority's Response on Further Information on GM Soybeans-Application A338. Australia New Zealand Food Authority, Canberra.

[30] Vazquez-Padron, R.I., Gonzales-Cabrera, J., Garcia-Tovar, C., Neri-Bazan, L., Lopez-Revilla, R., Hernandez, M., Moreno-Fierro, L. and de la Riva, G.A. (2000) CrylAc Protoxin from Bacillus thuringiensis sp. kurstaki HD73 Binds to Surface Proteins in the Mouse Small Intestine. Biochemical and Biophysical Research Communications, 271, 54-58. https://doi.org/10.1006/bbrc.2000.2584

[31] Fares, N.H. and El-Sayed, A.K. (1998) Fine Structural Changes in the Ileum of Mice Fed on Delta-Endotoxin-Treated Potatoes and Transgenic Potatoes. Natural Toxins, 6, 219-233. https://doi.org/10.1002/(SICI)1522-7189(199811/12)6:6<219::AID-NT30>3.0.CO;2- 
$\underline{\mathrm{K}}$

[32] OGTR (2016) Approved GMOs. Office of the Gene Technology Regulator. http://www.ogtr.gov.au/internet/ogtr/publishing.nsf/Content/section-approved-gm os

[33] ANZFA (2002) Final assessment Report (Inquiry-s.17). Application A416. Glyphosate-Tolerant Corn Line NK603. Australia and New Zealand Food Authority (ANZFA), Canberra.

[34] ANZFA. Final Analysis Report. Application A346. Food Produced from Insect-Protected Corn Line MON810. Australia and New Zealand Food Authority (ANZFA), Canberra.

[35] EFSA (2008) Application for Authorization of MON $863 \times$ MON $810 \times$ NK603 Maize in the European Union, According to Regulation (EC) No 1829/2003 on Genetically Modified Food and Feed. Part II Summary. EFSA, Parma.

[36] FSANZ (2003) Final Assessment Report: Application A484. Food from Insect-Protected MON863 Corn. Food Standards Australia New Zealand (FSANZ), Canberra.

[37] FSANZ (2006) Final Assessment Report. Application A548. Food from Corn Rootworm-Protected \& Glyphosate-Tolerant Corn MON88017. Food Standards Australia New Zealand (FSANZ), Canberra.

[38] Dixon, M.F., Genta, R.M., Yardley, J.H. and Correa, P. (1996) Classification and Grading of Gastritis. The Updated Sydney System. International Workshop on the Histopathology of Gastritis, Houston 1994. The American Journal of Surgical Pathology, 20, 1161-1181. https://doi.org/10.1097/00000478-199610000-00001

[39] Nicholson, D.W., Nicotera, P. and Melino, G. (2004) Caspases and Cell Death. In Encyclopedia of Biological Chemistry, 319-327.

https://doi.org/10.1016/B0-12-443710-9/00074-0

[40] Kim, W.H., Yeo, M., Kim, M.S., Chun, S.B., Shin, E.C., Park, J.H. and Park, I.S. (2000) Role of Caspase-3 in Apoptosis of Colon Cancer Cells Induced by Nonsteroidal Anti-Inflammatory Drugs. International Journal of Colorectal Disease, 15, 105-111. https://doi.org/10.1007/s003840050242

[41] Steller, H. (1995) Mechanisms and Genes of Cellular Suicide. Science, 267, 1445-1449. https://doi.org/10.1126/science.7878463

[42] Niimi, C., Goto, H., Ohmiya, N., Niwa, Y., Hayakawa, T., Nagasaka, T. and Nakashima, N. (2002) Usefulness of p53 and Ki-67 Immunohistochemical Analysis for Preoperative Diagnosis of Extremely Well-Differentiated Gastric Adenocarcinoma. American Journal of Clinical Pathology, 118, 683-692.

https://doi.org/10.1309/NYA1-V9KQ-NVF8-MA8M

[43] Vallejo-Cremades, M.T., Gómez de Segura, I.A., Gómez-Garcia, L., Pérez-Vicente, J. and De Miguel, E. (2005) A High-Protein Dietary Treatment to Intestinally Hypotrophic Rats Induces Ghrelin mRNA Content and Serum Peptide Level Changes. Clinical Nutrition, 24, 904-912. https://doi.org/10.1016/j.clnu.2005.05.018

[44] Loogna, P., Franzen, L., Sipponen, P. and Domellof, L. (2002) Cyclooxygenase-2 and Bcl-2 Expression in the Stomach Mucosa of Wistar Rats Exposed to Helicobacter Pylori, N'-methyl-N'-nitro-N-nitrosoguanidine and Bile. VirchowsArchiv. An International Journal of Pathology, 441, 77-84.

https://doi.org/10.1007/s00428-001-0571-z

[45] Li, H. and Helander, H.F. (1996) Hypergastrinemia Increases Proliferation of Gastroduodenal Epithelium during Gastric Ulcer Healing in Rats. Digestive Diseases 
and Sciences, 41, 40-48. https://doi.org/10.1007/BF02208582

[46] Yu, J., Tang, B.D., Leung, W.K., To, K.F., Bai, A.H.C., Zeng, Z.R., Ma, P.K., Go, M.Y.Y., Hu, P.J. and Sung, J.J.Y. (2005) Different Cell Kinetic Changes in Rat Stomach Cancer after Treatment with Celecoxib or Indomethacin: Implications on Chemoprevention. World Journal of Gastroenterology, 11, 41-45. https://doi.org/10.3748/wig.v11.i1.41

[47] Keefe, D.M., Brealey, J., Goland, G.J. and Cummins, A.G. (2000) Chemotherapy for Cancer Causes Apoptosis That Precedes Hypoplasia in Crypts of the Small Intestine in Humans. Gut, 47, 632-637. https://doi.org/10.1136/gut.47.5.632

[48] OECD (2012) Guidance Document 116 on the Conduct and Design of Chronic Toxicity and Carcinogenicity Studies, Supporting Test Guidelines 451, 452 and 453. 2nd Edition, OECD, Paris.

[49] Siglin, J.C. and Baker, W.H. (2002) Laboratory Animal Management. In: Derelanko, M.J. and Hollinger, M.A., Eds., Handbook of Toxicology, 2nd Edition, CRC Press, Boca Raton, 1-67.

[50] Kokue, E.I., Nakamura, T. and Hayama, T. (1977) Forestomach Lesions Induced by Starvation in Rat; Its Similarity with Gastroesophogeal Ulcer of Swine. Nihon JuigakuZasshi, 39, 337-341. https://doi.org/10.1292/jvms1939.39.337

[51] Amieva, M.R., Vogelmann, R., Covacci, A., Tompkins, L.S., Nelson, W.J. and Falkow, S. (2003) Disruption of the Epithelial Apical-Junctional Complex by Helicobacter Pylori CagA. Science, 300, 1430-1434.

https://doi.org/10.1126/science.1081919

[52] Eastwood, G.L. and Erdmann, K.R. (1978) Effect of Ethanol on Canine Gastric Epithelial Ultrastructure and Transmucosal Potential Difference. The American Journal of Digestive Diseases, 23, 429-435. https://doi.org/10.1007/BF01072926

[53] Meyer, R.A., McGinley, D. and Posalaky, Z. (1986) Effects of Aspirin on Tight Junction Structure of the Canine Gastric Mucosa. Gastroenterology, 91, 351-359. https://doi.org/10.1016/0016-5085(86)90568-8

[54] Owen, D.A. (2003) Gastritis and Carditis. Modern Pathology, 16, 325-341. https://doi.org/10.1097/01.MP.0000062995.72390.14

[55] Fenoglio-Preiser, C. (1998) Creating a Framework for Diagnosing the Benign Gastric Biopsy. Current Diagnostic Pathology, 5, 2-6. https://doi.org/10.1016/S0968-6053(98)80029-X

[56] Martin, G.R. and Wallace, J.L. (2006) Gastrointestinal Inflammation: A Central Component of Mucosal Defense and Repair. Experimental Biology and Medicine, 231, 130-137. https://doi.org/10.1177/153537020623100202

[57] Hirst, B.H. (2011) The Gastric Mucosal Barrier. Comprehensive Physiology, 279-308. https://doi.org/10.1002/cphy.cp060315

[58] Paimela, H., Goddard, P.J. and Silen, W. (1995) Present Views on Restitution of Gastrointestinal Epithelium. Digestive Diseases and Sciences, 40, 2495-2496. https://doi.org/10.1007/BF02063263

[59] Huber, D., Balda, M.S. and Matter, K. (2000) Occludin Modulates Transepithelial Migration of Neutrophils. The Journal of Biological Chemistry, 275, 5773-5778. https://doi.org/10.1074/jbc.275.8.5773

[60] Tsukita, S., Furuse, M. and Itoh, M. (2001) Multifunctional Strands in Tight Junctions. Nature Reviews. Molecular Cell Biology, 2, 285-293. https://doi.org/10.1038/35067088

[61] Weber, C.R., Nalle, S.C., Tretiakova, M., Rubin, D.T. and Turner, J.R. (2008) Clau- 
din-1 and Claudin-2 Expression Is Elevated in Inflammatory Bowel Disease and May Contribute to Early Neoplastic Transformation. Laboratory Investigation: $A$ Journal of Technical Methods and Pathology, 88, 1110-1120. https://doi.org/10.1038/labinvest.2008.78

[62] Laukoetter, M.G., Nava, P., Lee, W.Y., Severson, E.A., Capaldo, C.T., Babbin, B.A., Williams, I.R., Koval, M., Peatman, E., Campbell, J.A., Dermody, T.S., Nusrat, A. and Parkos, C.A. (2007) JAM-A Regulates Permeability and Inflammation in the Intestine in Vivo. The Journal of Experimental Medicine, 204, 3067-3076.

https://doi.org/10.1084/jem.20071416

[63] Martìn-Padura, I., Lostaglio, S., Schneemann, M., Williams, L., Romano, M., Fruscella, P., Panzeri, C., Stoppacciaro, A., Ruco, L., Villa, A., Simmons, D. and Dejana, E. (1998) Junctional Adhesion Molecule, a Novel Member of the Immunoglobulin Superfamily That Distributes at Intercellular Junctions and Modulates Monocyte Transmigration. The Journal of Cell Biology, 142, 117-127.

https://doi.org/10.1083/jcb.142.1.117

[64] Saitou, M., Furuse, M., Sasaki, H., Schulzke, J.D., Fromm, M., Takano, H., Noda, T. and Tsukita, S. (2000) Complex Phenotype of Mice Lacking Occludin, a Component of Tight Junction Strands. Molecular Biology of the Cell, 11, 4131-4142. https://doi.org/10.1091/mbc.11.12.4131

[65] Sawada, N., Murata, M., Kikuchi, K., Osanai, M., Tobioka, H., Kojima, T. and Chiba, H. (2003) Tight Junctions and Human Diseases. Medical Electron Microscopy: Official Journal of the Clinical Electron Microscopy Society of Japan, 36, 147-156. https://doi.org/10.1007/s00795-003-0219-y

[66] Desai, T.R., Leeper, N.J., Hynes, K.L. and Gewertz, B.L. (2002) Interleukin-6 Causes Endothelial Barrier Dysfunction via the Protein Kinase C Pathway. The Journal of Surgical Research, 104, 118-123. https://doi.org/10.1006/jsre.2002.6415

[67] Soler, A.P., Mullin, J.M., Knudsen, K.A. and Marano, C.W. (1996) Tissue Remodeling during Tumor Necrosis Factor-Induced Apoptosis in LLC-PK1 Renal Epithelial Cells. American Journal of Physiology-Renal Physiology, 270, F869-F879. https://doi.org/10.1152/ajprenal.1996.270.5.F869

[68] Betz, F.S., Hammond, B.G. and Fuchs, R.L. (2000) Safety and Advantages of Bacillus thuringiensis-Protected Plants to Control Insect Pests. Regulatory Toxicology and Pharmacology, 32, 156-173. https://doi.org/10.1006/rtph.2000.1426

[69] Pigott, C.R. and Ellar, D.J. (2007) Role of Receptors in Bacillus thuringiensis Crystal Toxin Activity. Microbiology and Molecular Biology Reviews: MMBR, 71, 255-281. https://doi.org/10.1128/MMBR.00034-06

[70] Hofte, H. and Whiteley, H.R. (1989) Insecticidal Crystal Proteins of Bacillus thuringiensis. Microbiological Reviews, 53, 242-255.

[71] Schnepf, E., Crickmore, N., Van Rie, J., Lereclus, D., Baum, J., Feitelson, J., Zeigler, D.R. and Dean, D.H. (1998) Bacillus thuringiensis and Its Pesticidal Crystal Proteins. Microbiology and Molecular Biology Review, 62, 775-806.

[72] Vaeck, M., Reynaerts, A., Hofte, H., Jansens, S., De Beuckeleer, M., Dean, C., Zabeau, M., Van Montagu, M. and Leemans, J. (1987) Transgenic Plants Protected from Insect Attack. Nature, 328, 33-37. https://doi.org/10.1038/328033a0

[73] Shimada, N., Miyamoto, K., Kanda, K. and Murata, H. (2006) Binding of Cry1Ab toxin, a Bacillus thuringiensis Insecticidal Toxin, to Proteins of the Bovine Intestinal Epithelial Cell: An in Vitro Study. Applied Entomology and Zoology, 41, 295-301. https://doi.org/10.1303/aez.2006.295

[74] Capaldo, C.T. and Nusrat, A. (2009) Cytokine Regulation of Tight Junctions. Bio- 
chimica et Biophysica Acta (BBA) - Biomembranes, 1788, 864-871.

https://doi.org/10.1016/j.bbamem.2008.08.027

[75] Freire, I.S., Miranda-Vilela, A.L., Barbosa, L.C., Martins, E.S., Monnerat, R.G. and Grisolia, C.K. (2014) Evaluation of Cytotoxicity, Genotoxicity and Hematotoxicity of the Recombinant Spore-Crystal Complexes Cry1Ia, Cry10Aa and Cry1Ba6 from Bacillus thuringiensis in Swiss Mice. Toxins, 6, 2872-2885. https://doi.org/10.3390/toxins6102872

[76] Kooistra, L.H. and Nyska, A. (2014) Stomach, Forestomach-Cyst. In: Cesta, M.F., Herbert, R.A., Brix, A., Malarkey, D.E. and Sills, R.C., Eds., National Toxicology Program Nonneoplastic Lesion Atlas. https://ntp.niehs.nih.gov/nnl/alimentary/forestomach/cyst/index.htm

[77] Frantz, J., Betton, G., Cartwright, M., Crissman, J., Macklin, A. and Maronpot, R. (1991) Proliferative Lesions of the Non-Glandular and Glandular Stomach in Rats, Guides for Toxicologic Pathology. STP/ARP/AFIP, Washington.

[78] Kikuchi, M., Nagata, H., Watanabe, N., Watanabe, H., Tatemichi, M. and Hibi, T. (2010) Altered Expression of a Putative Progenitor Cell Marker DCAMKL1 in the Rat Gastric Mucosa in Regeneration, Metaplasia and Dysplasia. BMC Gastroenterology, 10, 65. https://doi.org/10.1186/1471-230X-10-65

[79] Şener, G., Paskaloglu, K., Kapucu, C., Cetinel, S., Contuk, G. and Ayanoğlu-Dülger, G. (2004) Octreotide Ameliorates Alendronate-Induced Gastric Injury. Peptides, 25, 115-121. https://doi.org/10.1016/j.peptides.2003.11.017

[80] Tarnawski, A., Douglass, T.G., Stachura, J. and Krause, W.J. (1991) Quality of Gastric Ulcer Healing: Histological and Ultrastructural Assessment. Alimentary Pharmacology and Therapeutics, 5, 79-90. https://doi.org/10.1111/j.1365-2036.1991.tb00751.x

[81] Gärtner, K. (2002) The Forestomach of Rats and Mice, an Effective Device Supporting Digestive Metabolism in Muridae (Review). Journal of Experimental Animal Science, 42, 1-20. https://doi.org/10.1016/S0939-8600(02)80002-5

[82] Ito, S., Lacy, E.R., Rutten, M.J., Critchlow, J. and Silen, W. (1984) Rapid Repair of Injured Gastric Mucosa. Scandinavian Journal of Gastroenterology, 101, 87-95.

[83] Cui, R.T., Cai, G., Yin, Z.B., Cheng, Y., Yang, Q.H. and Tian, T. (2001) Transretinoic acid Inhibits Rats Gastric Epithelial Dysplasia Induced by $\mathrm{N}$-methyl-N-nitro-N-nitrosoguanidine: Influences on Cell Apoptosis and Expression of Its Regulatory Genes. World Journal of Gastroenterology, 7, 394-398. https://doi.org/10.3748/wjg.v7.i3.394

[84] Hammond, B.G., Dudek, R., Lemen, J.K. and Nemeth, M. (2004) Results of a 13 Week Safety Assurance Study with Rats Fed Grain from Glyphosate Tolerant Corn. Food and Chemical Toxicology, 42, 1003-1014.

https://doi.org/10.1016/j.fct.2004.02.013

[85] Hammond, B., Dudek, R., Lemen, J.K. and Nemeth, M.A. (2006a) Results of a 90-Day Safety Assurance Study with Rats Fed Grain from Corn Borer-Protected Corn. Food and Chemical Toxicology, 44, 1092-1099.

https://doi.org/10.1016/j.fct.2006.01.003

[86] Hammond, B., Lemen, J., Dudek, R., Ward, D., Jiang, C., Nemeth, M. and Burns, J. (2006b) Results of a 90-Day Safety Assurance Study with Rats Fed Grain from Corn Rootworm-Protected Corn. Food and Chemical Toxicology, 44, 147-160. https://doi.org/10.1016/j.fct.2005.06.008

[87] Healy, C., Hammond, B. and Kirkpatrick, J. (2008) Results of a 13-Week Safety Assurance Study with Rats Fed Grain from Corn Rootworm-Protected, Glypho- 
sate-Tolerant MON 88017 Corn. Food and Chemical Toxicology, 46, 2517-2524. https://doi.org/10.1016/j.fct.2008.04.005

[88] Qi, X., He, X., Luo, Y., Li, S., Zou, S., Cao, S., Tang, M., Delaney, B., Xu, W. and Huang, K. (2012) Subchronic Feeding Study of Stacked Trait Genetically-Modified Soybean (3Ø5423 $\times 40-3-2)$ in Sprague-Dawley Rats. Food and Chemical Toxicology, 50, 3256-3263. https://doi.org/10.1016/j.fct.2012.06.052

[89] Zhu, Y., Li, D., Wang, F., Yin, J. and Jin, H. (2004) Nutritional Assessment and Fate of DNA of Soybean Meal from Roundup Ready or Conventional Soybeans Using Rats. Archives of Animal Nutrition, 58, 295-310. https://doi.org/10.1080/00039420412331273277

[90] Godlewski, M.M., Bierła, J.B., Strzałkowski, A., Martinez-Puig, D., Pająk, B., Kotunia, A., Chetrit, C. and Zabielski, R. (2009) A Novel Cytometric Approach to Study Intestinal Mucosa Rebuilding in Weaned Pigs Fed with Dietary Nucleotides. Livestock Science, 123, 215-220. https://doi.org/10.1016/j.livsci.2008.11.012

[91] Howarth, G.S., Francis, G.L., Cool, J.C., Xu, X., Byard, R.W. and Read, L.C. (1996) Milk Growth Factors Enriched from Cheese Whey Ameliorate Intestinal Damage by Methotrexate When Administered Orally to Rats. Journal of Nutrition, 126, 2519-2530. https://doi.org/10.1093/jn/126.10.2519

[92] Logan, R.M., Stringer, A.M., Bowen, J.M., Gibson, R.J., Sonis, S.T. and Keefe, D.M. (2009) Is the Pathobiology of Chemotherapy-Induced Alimentary Tract Mucositis Influenced by the Type of Mucotoxic Drug Administered? Cancer Chemotherapy and Pharmacology, 63, 239-251. https://doi.org/10.1007/s00280-008-0732-8

[93] Staibano, S., Rocco, A., Mezza, E., De Rosa, G., Budillon, G. and Nardone, G. (2002) Diagnosis of Chronic Atrophic Gastritis by Morphometric Image Analysis. A New Method to Overcome the Confounding Effect of the Inflammatory Infiltrate. The Journal of Pathology, 198, 47-54. https://doi.org/10.1002/path.1173

[94] Strzalkowski, A.K., Godlewski, M.M., Hallay, N., Kulasek, G., Gajewski, Z. and Zabielski, R. (2007) The Effect of Supplementing Sow with Bioactive Substances on Neonatal Small Intestinal Epithelium. Journal of Physiology and Pharmacology, 58, 115-122.

[95] Sukhotnik, I., Shehadeh, N., Coran, A.G., Mogilner, J.G., Karry, R., Shamian, B., Ure, B.M. and Shamir, R. (2008) Oral Insulin Enhances Cell Proliferation and Decreases Enterocyte Apoptosis during Methotrexate-Induced Mucositis in the Rat. Journal of Pediatric Gastroenterology and Nutrition, 47, 115-122. https://doi.org/10.1097/MPG.0b013e31806008f1

[96] Sakamoto, Y., Tada, Y., Fukumori, N., Tayama, K., Ando, H., Takahashi, H., Kubo, Y., Nagasawa, A., Yano, N., Yuzawa, K., Ogata, A. and Kamimura, H. (2007) [A 52-Week Feeding Study of Genetically Modified Soybeans in F344 Rats]. Shokuhineiseigakuzasshi. Journal of the Food Hygienic Society of Japan, 48, 41-50. https://doi.org/10.3358/shokueishi.48.41

[97] Claude, P. and Goodenough, D.A. (1973) Fracture Faces of Zonulae Occludentes from "Tight" and "Leaky" Epithelia. Journal of Cell Biology, 58, 390-400. https://doi.org/10.1083/jcb.58.2.390

[98] Fujita, H., Chiba, H., Yokozaki, H., Sakai, N., Sugimoto, K., Wada, T., Kojima, T., Yamashita, T. and Sawada, N. (2006) Differential Expression and Subcellular Localization of Claudin-7, -8, -12, -13, and -15 along the Mouse Intestine. The Journal of Histochemistry and Cytochemistry: Official Journal of the Histochemistry Society, 54, 933-944. https://doi.org/10.1369/jhc.6A6944.2006

[99] Nusrat, A., von Eichel-Streiber, C., Turner, J.R., Verkade, P., Madara, J.L. and Par- 
kos, C.A. (2001) Clostridium difficile Toxins Disrupt Epithelial Barrier Function by Altering Membrane Microdomain Localization of Tight Junction Proteins. Infection and Immunity, 69, 1329-1336. https://doi.org/10.1128/IAI.69.3.1329-1336.2001

[100] Markov, A., Veshnyakova, A., Fromm, M., Amasheh, M. and Amasheh, S. (2010) Segmental Expression of Claudin Proteins Correlates with Tight Junction Barrier Properties in Rat Intestine. Journal of Comparative Physiology B, 180, 591-598. https://doi.org/10.1007/s00360-009-0440-7

[101] Pelton, N.S., Tivey, D.R., Howarth, G.S., Davidson, G.P. and Butler, R.N. (2004) A Novel Breath Test for the Non-Invasive Assessment of Small Intestinal Mucosal Injury Following Methotrexate Administration in the Rat. Scandinavian Journal of Gastroenterology, 39, 1015-1016. https://doi.org/10.1080/00365520410003416

[102] Soler, A.P., Miller, R.D., Laughlin, K.V., Carp, N.Z., Klurfeld, D.M. and Mullin, J.M. (1999) Increased Tight Junctional Permeability Is Associated with the Development of Colon Cancer. Carcinogenesis, 20, 1425-1431.

https://doi.org/10.1093/carcin/20.8.1425 